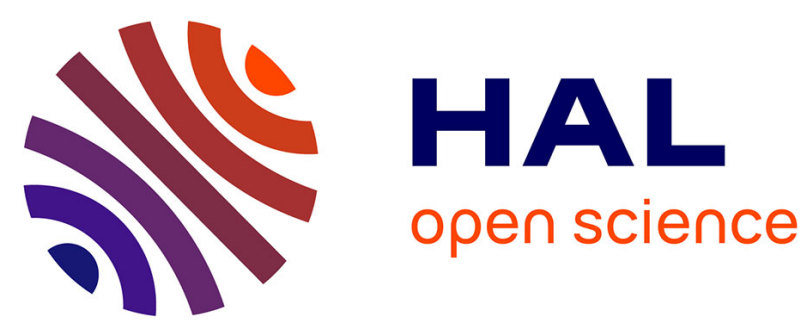

\title{
Apparent partial loss age spectra of Neoarchean hornblende (Murmansk Terrane, Kola Peninsula, Russia): the role of biotite inclusions revealed by 40Ar/39Ar laserprobe analysis
}

Koenraad de Jong, Jan R. Wijbrans

\section{To cite this version:}

Koenraad de Jong, Jan R. Wijbrans. Apparent partial loss age spectra of Neoarchean hornblende (Murmansk Terrane, Kola Peninsula, Russia): the role of biotite inclusions revealed by $40 \mathrm{Ar} / 39 \mathrm{Ar}$ laserprobe analysis. Terra Nova, 2006, 18, pp.353-364. hal-00109454

\section{HAL Id: hal-00109454 \\ https://hal-insu.archives-ouvertes.fr/hal-00109454}

Submitted on 14 Dec 2007

HAL is a multi-disciplinary open access archive for the deposit and dissemination of scientific research documents, whether they are published or not. The documents may come from teaching and research institutions in France or abroad, or from public or private research centers.
L'archive ouverte pluridisciplinaire HAL, est destinée au dépôt et à la diffusion de documents scientifiques de niveau recherche, publiés ou non, émanant des établissements d'enseignement et de recherche français ou étrangers, des laboratoires publics ou privés. 


\title{
Apparent partial loss age spectra of Neoarchean hornblende (Murmansk Terrane, Kola Peninsula, Russia): the role of biotite inclusions revealed by ${ }^{40} \mathrm{Ar} /{ }^{39} \mathrm{Ar}$ laserprobe analysis
}

\author{
Koen de Jong ${ }^{1}$ and Jan R. Wijbrans ${ }^{2}$ \\ 'Institut des Sciences de la Terre d'Orléans, UMR 6113, Université d'Orléans, 45067 Orléans7 Cedex 2, France; \\ e-mail: koen.dejong@univ-orleans.fr or keuntie@netscape.net \\ ${ }^{2}$ Department of Isotope Geochemistry, Faculty of Life and Earth Sciences, Vrije Universiteit, Amsterdam, The Netherlands
}

\begin{abstract}
Metamorphic hornblende frequently yields spectra with progressively increasing ${ }^{40} \mathrm{Ar} /{ }^{39} \mathrm{Ar}$ age steps, often interpreted as caused by partial resetting due to thermally activated radiogenic argon loss by solid-state diffusion. Yet, in many cases rising $\mathrm{Ca} / \mathrm{K}$ ratio spectra for such samples imply the presence of minor inclusions of K-contaminant minerals. To avoid parts of grains with mineral inclusions or compositional zoning we drilled tiny discs from thin sections under a petrographic microscope. Laser step-heating of drilled biotite-free hornblende discs yielded flat age and ratio spectra. In contrast,
\end{abstract}

furnace step-heated hornblende separates from the same samples produced apparent loss age spectra. Moreover, biotite-free samples yielded flat spectra by laser and furnace dating. Consequently, apparent loss spectra result from degassing of included substantially younger biotite before its hornblende host during laboratory step-heating; c. $2640 \mathrm{Ma}$ hornblende ages constrain the Murmansk Terrane's cooling.

Terra Nova, 18, 353-364, 2006 @ 2006 Blackwell Publishing Ltd doi: 10.1111/j.1365-3121.2006.00699.x

\section{Introduction}

${ }^{40} \mathrm{Ar} /{ }^{39} \mathrm{Ar}$ age spectra with progressively rising apparent ages have been widely interpreted as caused by partial argon loss by diffusion during younger thermotectonic reworking or slow cooling (Turner, 1969; Dallmeyer, 1975; Harrison and McDougall, 1980; Berry and McDougall, 1986; Wijbrans and McDougall, 1987; Lister and Baldwin, 1996). Younger apparent ages for the early gas release during laboratory step-heating experiments were assumed to reflect the intragrain spatial distribution of argon in samples. However, abundant evidence exists that a large portion of Ar release during step-heating of amphiboles under vacuum occurs due to chemical and structural changes within the crystals, rather than by volume diffusion (Gaber et al., 1988; Lee et al., 1991; Wartho et al., 1991; Wartho, 1995a). Consequentely, Ar may be released simultaneously from cores and rims of crystals, leading to homogenisation of age gradients (Lee et al., 1990; Kelley and Turner, 1991; Lee, 1993). This clearly implies that age plateaux can not a priori be interpreted simply as reflecting crystal lattices with homogeneously distributed Ar and that minerals have been unaffected by Ar loss or gain. It similarly brings into question the interpretation that age spectra with progressively increasing apparent ages may point toAr loss by volume diffusion - the classic interpretation. Trends in ${ }^{40} \mathrm{Ar} /{ }^{39} \mathrm{Ar}$ age and $\mathrm{Ca} / \mathrm{K}$ and $\mathrm{Cl} / \mathrm{K}$ ratio proxies for ${ }^{37} \mathrm{Ar}_{\mathrm{Ca}}{ }^{39} \mathrm{Ar}_{\mathrm{K}}$ and ${ }^{38} \mathrm{Ar}_{\mathrm{Cl}}{ }^{39} \mathrm{Ar}_{\mathrm{K}}$, respectively - spectra for hornblende are often related, pointing to degassing of a heterogeneous phase. This may be due to chemical zonation of hornblende, the presence of exsolution features and/or included contaminant minerals (Berger, 1975; Berry and McDougall, 1986; Harrison and Fitz Gerald, 1986; Onstott and Peacock, 1987; Onstott and Pringle-Goodell, 1988; Ross and Sharp, 1988; von Blanckenburg and Villa, 1988; Baldwin et al., 1990; Kelley and Turner, 1991; Lee, 1993; Rex et al., 1993; Lo and Onstott, 1995; Wartho, 1995b; Villa et al., 1996, 2000; Ahn and Cho, 1998; Belluso et al., 2000).
To shed further light on the phenomenon of apparent partial loss age spectra we concentrated on hornblendes from the Murmansk Terrane that experienced a tectonometamorphic evolution of about 1 billion years. We combined classic furnace step-heating of hornblende and biotite separates with laserprobe step-heating of tiny discs that were drilled from carefully selected inclusion-free hornblende grains in thin sections under a petrographic microscope, using the technique of Verschure (1978).

\section{Murmansk Terrane and the Lapland-Kola Orogen}

The Murmansk Terrane (MT) is one of the Neoarchaean terranes in the Palaeoproterozoic LaplandKola Orogen in the Kola Peninsula of Arctic European Russia (Fig. 1) and separated from the other terranes by the northwest-trending subvertical Murmansk Shear Zone (Fig. 2). The MT predominantly comprises amphibolite-facies, leuco- to mesocratic, tonalitic, trondhjemitic to granodioritic gneisses and intrusives with 
subordinate metasedimentary material (Batiyeva and Bel'kov, 1968; Mitrofanov, 2001). The few $\mathrm{Rb}-\mathrm{Sr}$ whole-rock isochrons and $\mathrm{U}-\mathrm{Pb}$ zircon ages for tonalitic gneisses and a variety of enderbites to granites span 2.6-2.8 Ga (Vetrin, 1988; Pushkarev, 1990; Balashov et al., 1992). Sm$\mathrm{Nd}(\mathrm{Dm})$ model ages are between
2.68 and $3.06 \mathrm{Ga}$ (Timmerman and Daly, 1995; Timmerman, 1996).

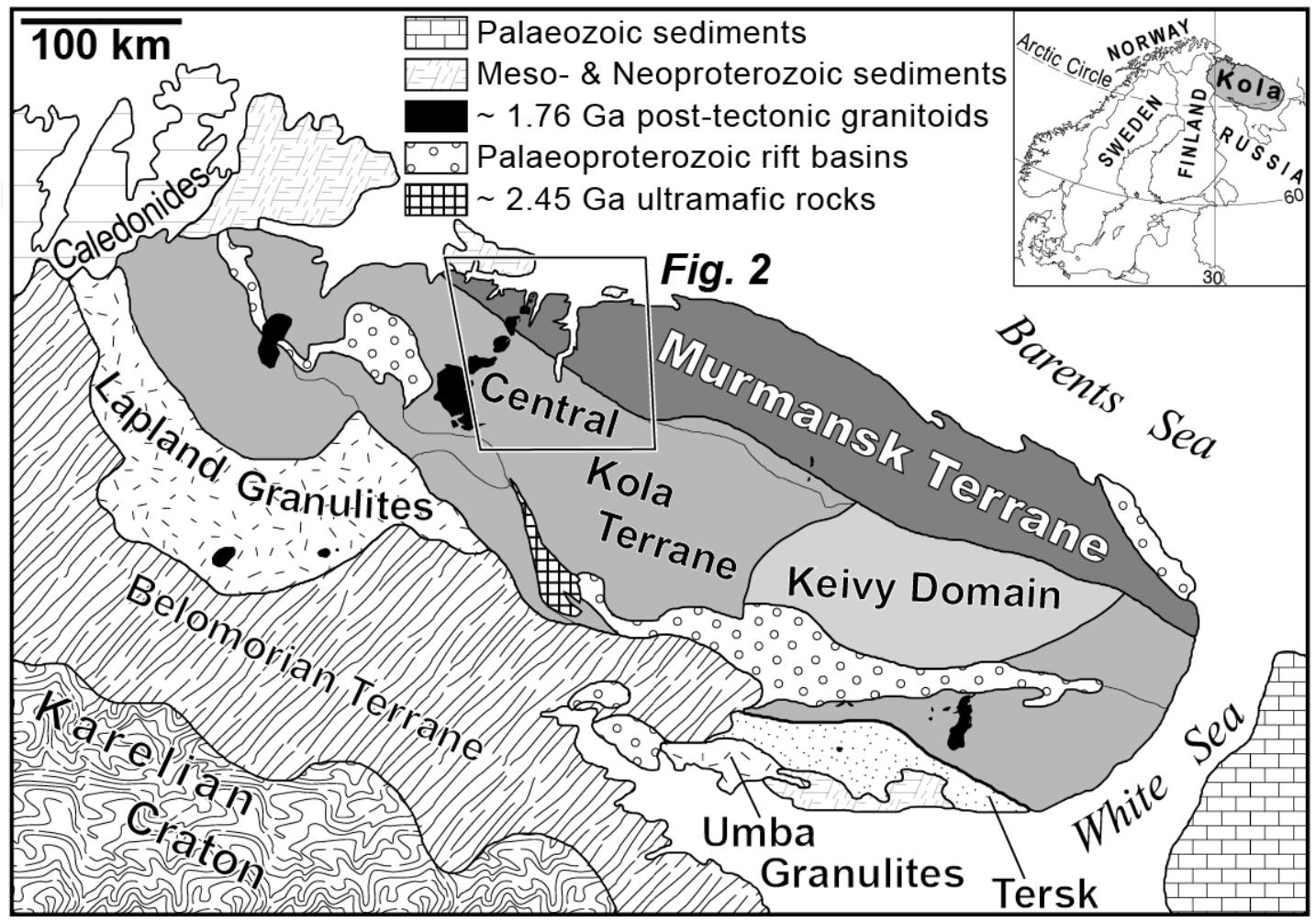

Fig. 1 Tectonic sketch map of the Kola Peninsula, modified after Timmerman (1996) and Daly et al. (2001). The location of Fig. 2 with position of the samples is outlined.

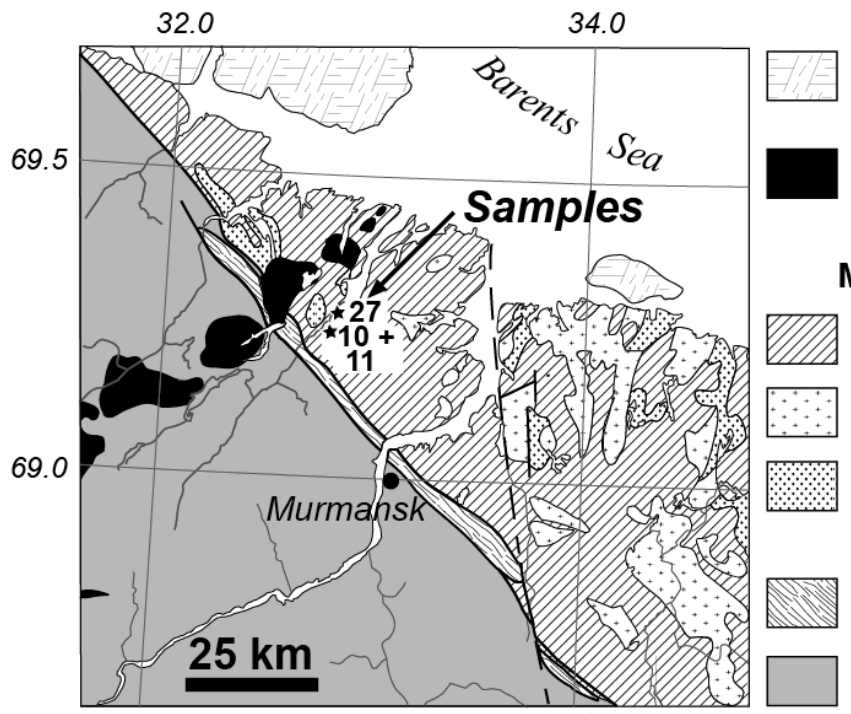

\section{Neoproterozoic clastic rocks}

Litsa - Ara-Guba intrusives (1.76 Ga)

Granodiorite, granite, leucogranite

\section{MURMANSK TERRANE}

Granodiorite, tonalite, trondhjemite, enderbite

Leucogranite, granodiorite

Enderbite, diorite, monzodiorite, granodiorite

\section{Murmansk Shear Zone}

Mica-rich quartz-feldspar mylonites

Central Kola Terrane (undiff.)

Fig. 2 Geological map of the area around Murmansk, modified after Mitrofanov (2001), with the sample localities: MT-10 and MT-11 . All samples have been taken well outside the area affected by retrogression and mylonitization related to the Murmansk Shear Zone and the contact aureole of the Litsa-Araguba intrusions. Minor Phanerozoic dolerites omitted. Lambert conformal conical projection.

Following major crustal stretching at $c a .2 .45$ Ga (Timmerman, 1996; Balagansky et al., 2001) the orogen was at least partly peneplaned in the earliest Palaeoproterozoic (Zagorodny,
1982; Sturt et al., 1994; Bridgwater et al., 2001). Subduction of oceanic crust led to 
accretion of 1.96-1.91 Ga juvenile island arcs and terranes. Granuliteand amphibolite-facies metamorphism occurred in the orogen's suture zone at 1.92-1.90 Ga (Timmerman, 1996; Daly et al., 2001). At about $1.76 \mathrm{Ga}$ (Vetrin et al., 2002) stitching plutons intruded terrane boundaries (Figs. 1, 2). Mica, when not affected by excess or inherited argon, yielded 1.75-1.70 $\mathrm{Ga}{ }^{40} \mathrm{Ar} /{ }^{39} \mathrm{Ar}$ plateau ages in the Central Kola and Belomorian Terranes and the northernmost part of the Archaean Karelian Craton (Fig. 1; de Jong et al., 1999).

\section{Petrography and mineral chemistry}

Coarse-grained tonalitic gneiss MT-10 truncates an ill-defined sub-vertical principal gneissic layering. The main constituents quartz, oligoclase (An 25-28) and microcline define a high-grade equilibrium microstructure with straight or slightly curved highangle mutual boundaries, without preferred orientation. Quartz occurs as equi-dimensional inclusions in feldspar, or may be concentrated in small crystals between feldspar grains at triple or quadruple points. Blue-green hornblende $\quad(<500 \quad \mu \mathrm{m}$ perpendicular to c-axes) is a minor constituent. Crystals are optically unzoned and electron probe microanalysis (EPMA) indicates a homogeneous composition (Tab. 1; Fig. 3).

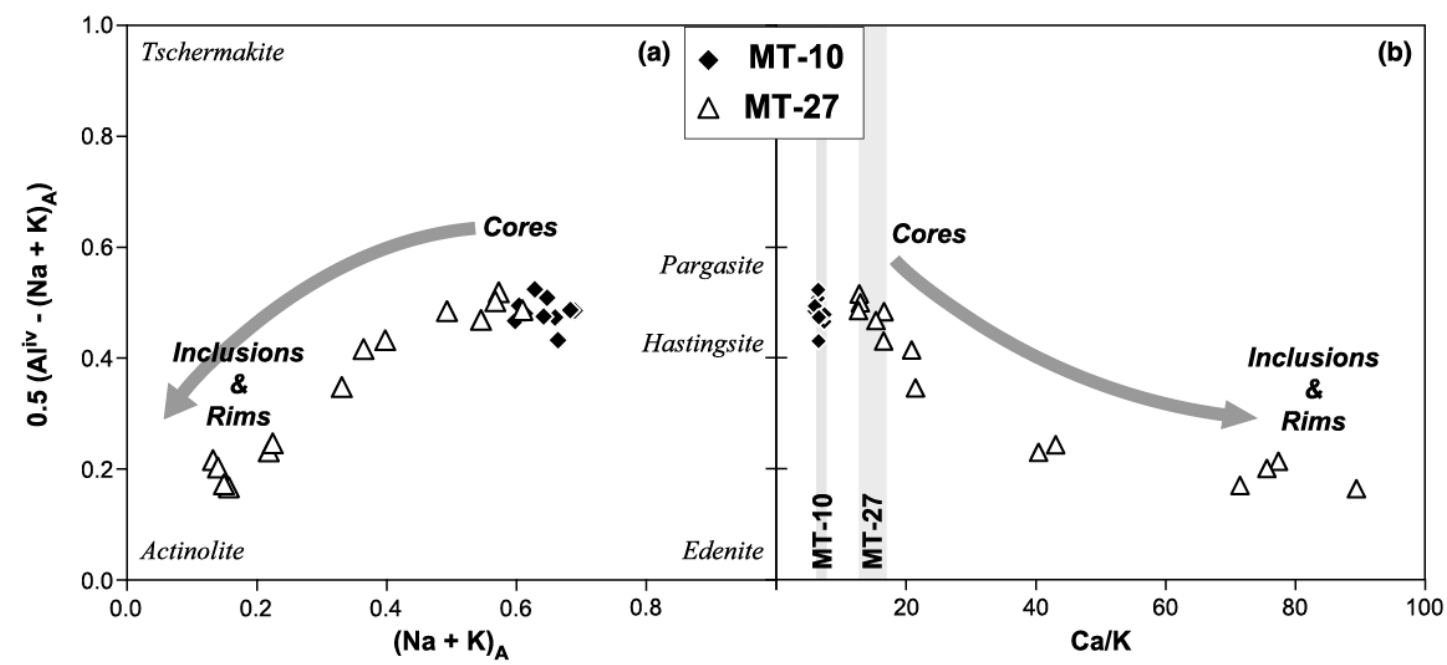

Fig. 3 Composition diagrams for cores and rims of amphibole in tonalitic gneiss MT-10 and amphibolite MT-27 from the Murmansk Terrane; 0.5 (Al iv) $(\mathrm{Na}+\mathrm{K}) \quad$ A) vs. $(\mathrm{Na}+\mathrm{K}) \quad$ A (a) and vs. $\mathrm{Ca} / \mathrm{K}(\mathrm{b})$. Grey vertical bars (b) $\mathrm{Ca} / \mathrm{K}$ ratios obtained from ${ }^{40} \mathrm{Ar} /{ }^{39} \mathrm{Ar}$ laserprobe and furnace step-heating for main degassing of amphibole. For electron probe microanalysis data and analytical details, see footnote to Table 1.

Small crystals $(<100 \mu \mathrm{m})$ of greenish biotite are partially replacing hornblende along cleavage planes (biotite's (001) parallel to amphibole's (110)), lattice imperfections, or form thin aggregates along grain boundaries. In the matrix, 200-500 $\mu \mathrm{m}$ biotite crystals occur as aggregates with low-angle rational impingement boundaries forming a decussate equilibrium microstructure. Biotite occurs intergrown with retrograde titanite (with ilmenite cores), epidote/clinozoisite and minor calcite (locally as veinlets). Matrix biotites are 0.43-0.46 phlogopites with 0.29-0.42 tschermak exchange component p.f.u. (Tab. 1).

MT-11 forms a lineated and foliated amphibolite band in gneiss MT-10. Variations in modal amounts of preferredly orientated plagioclase and green hornblende define a gneissic layering at the scale of several millimeters, along which brown biotite crystals have grown. Quartz is rare. Hornblende crystals (>2500 $\mu \mathrm{m}$ wide) may show some zoning towards lighter shades of green in rims and fractures and inside crystals too, giving rise to a mottled effect. Hornblende is locally replaced by biotite along lattice imperfections, cleavages and grain boundaries. 
Table 1 Representative electron probe micro-analyses of amphibole and biotite from the Murmansk Terrane

\begin{tabular}{|c|c|c|c|c|c|c|c|c|c|c|}
\hline MT-10 hornblende & Core & Core & Core & Rim & Rim & Core & Rim & Rim & Core & Core \\
\hline \multicolumn{11}{|l|}{ Wt.\% } \\
\hline $\mathrm{SiO}_{2}$ & 41.18 & 41.24 & 42.47 & 41.48 & 41.45 & 42.51 & 42.22 & 42.19 & 41.92 & 42.01 \\
\hline $\mathrm{TiO}_{2}$ & 1.00 & 1.10 & 0.81 & 0.83 & 1.28 & 1.56 & 1.26 & 0.87 & 0.99 & 1.13 \\
\hline $\mathrm{Al}_{2} \mathrm{O}_{3}$ & 11.51 & 11.67 & 11.07 & 11.31 & 11.62 & 11.33 & 10.95 & 11.30 & 11.41 & 10.90 \\
\hline $\mathrm{Cr}_{2} \mathrm{O}_{3}$ & 0.00 & 0.00 & 0.07 & 0.05 & 0.11 & 0.13 & 0.00 & 0.00 & 0.00 & 0.07 \\
\hline $\mathrm{Fe}_{2} \mathrm{O}_{3}$ & 4.17 & 3.21 & 3.79 & 5.34 & 2.92 & 3.52 & 1.60 & 3.68 & 3.28 & 5.35 \\
\hline $\mathrm{FeO}$ & 17.30 & 18.31 & 17.53 & 16.59 & 18.10 & 17.96 & 19.02 & 18.05 & 17.54 & 15.52 \\
\hline $\mathrm{MnO}$ & 0.62 & 0.58 & 0.51 & 0.59 & 0.52 & 0.50 & 0.57 & 0.64 & 0.61 & 0.44 \\
\hline $\mathrm{MgO}$ & 7.58 & 7.34 & 7.83 & 7.94 & 7.61 & 7.73 & 7.68 & 7.53 & 7.95 & 8.10 \\
\hline $\mathrm{CaO}$ & 11.37 & 11.45 & 11.41 & 11.50 & 11.50 & 11.31 & 11.66 & 11.49 & 11.52 & 11.33 \\
\hline $\mathrm{Na}_{2} \mathrm{O}$ & 1.22 & 1.28 & 1.20 & 1.18 & 1.38 & 1.05 & 1.28 & 1.25 & 1.27 & 1.26 \\
\hline $\mathrm{K}_{2} \mathrm{O}$ & 1.44 & 1.57 & 1.26 & 1.44 & 1.39 & 1.55 & 1.45 & 1.25 & 1.46 & 1.39 \\
\hline $\mathrm{H}_{2} \mathrm{O}$ & 1.87 & 1.88 & 1.93 & 1.85 & 1.90 & 1.96 & 1.90 & 1.92 & 1.89 & 1.93 \\
\hline $\mathrm{F}$ & 0.09 & 0.10 & 0.04 & 0.17 & 0.09 & 0.02 & 0.09 & 0.05 & 0.12 & 0.02 \\
\hline $\mathrm{a}$ & 0.04 & 0.03 & 0.00 & 0.01 & 0.02 & 0.00 & 0.01 & 0.00 & 0.00 & 0.02 \\
\hline total & 99.39 & 99.76 & 99.92 & 100.29 & 99.90 & 101.14 & 99.70 & 100.23 & 99.97 & 99.46 \\
\hline $\mathrm{O}_{1 / 4} \mathrm{~F}$ & 0.04 & 0.04 & 0.01 & 0.07 & 0.04 & 0.00 & 0.04 & 0.02 & 0.05 & 0.00 \\
\hline $\mathrm{O}_{1 / 4} \mathrm{Cl}$ & 0.00 & 0.00 & 0.00 & 0.00 & 0.00 & 0.00 & 0.00 & 0.00 & 0.00 & 0.00 \\
\hline total' & 99.34 & 99.71 & 99.90 & 100.21 & 99.86 & 101.13 & 99.66 & 100.21 & 99.91 & 99,45 \\
\hline $\begin{array}{l}\text { Fe[t] as } \mathrm{FeO} \\
\text { pfu }\end{array}$ & 21.06 & 21.20 & 20.94 & 21.40 & 20.73 & 21.13 & 20.46 & 21.36 & 20.48 & 20.34 \\
\hline Si & 6.336 & 6.339 & 6.468 & 6.324 & 6.344 & 6.406 & 6.473 & 6.427 & 6.396 & 6.408 \\
\hline $\mathrm{Ti}$ & 0.115 & 0.127 & 0.093 & 0.096 & 0.148 & 0.177 & 0.146 & 0.100 & 0.113 & 0.129 \\
\hline Al & 2.087 & 2.114 & 1.986 & 2.032 & 2.097 & 2.013 & 1.979 & 2.028 & 2.052 & 1.960 \\
\hline $\mathrm{Cr}$ & 0.000 & 0.000 & 0.008 & 0.006 & 0.014 & 0.015 & 0.001 & 0.000 & 0.000 & 0.008 \\
\hline $\mathrm{Fe}^{3+}$ & 0.483 & 0.371 & 0.434 & 0.613 & 0.337 & 0.399 & 0.184 & 0.422 & 0.376 & 0.614 \\
\hline $\mathrm{Fe}^{2+}$ & 2.226 & 2.354 & 2.232 & 2.115 & 2.316 & 2.264 & 2.439 & 2.299 & 2.238 & 1.980 \\
\hline Mn & 0.080 & 0.076 & 0.066 & 0.077 & 0.068 & 0.064 & 0.074 & 0.083 & 0.079 & 0.057 \\
\hline $\mathrm{Mg}$ & 1.738 & 1.680 & 1.777 & 1.803 & 1.735 & 1.737 & 1.755 & 1.709 & 1.807 & 1.842 \\
\hline $\mathrm{Ca}$ & 1.874 & 1.886 & 1.861 & 1.878 & 1.885 & 1.827 & 1.916 & 1.875 & 1.884 & 1.851 \\
\hline $\mathrm{Na}$ & 0.365 & 0.381 & 0.353 & 0.348 & 0.411 & 0.307 & 0.380 & 0.369 & 0.375 & 0.371 \\
\hline K & 0.282 & 0.309 & 0.245 & 0.280 & 0.272 & 0.297 & 0.284 & 0.244 & 0.284 & 0.271 \\
\hline total & 15.587 & 15.636 & 15.524 & 15.569 & 15.626 & 15.506 & 15.631 & 15.555 & 15.605 & 15.49 \\
\hline $\mathrm{Al}(\mathrm{iv})$ & 1.664 & 1.661 & 1.532 & 1.676 & 1.656 & 1.594 & 1.527 & 1.573 & 1.604 & 1.592 \\
\hline mg num & 0.438 & 0.416 & 0.443 & 0.460 & 0.428 & 0.434 & 0.418 & 0.426 & 0.447 & 0.48 \\
\hline A site & 0.647 & 0.690 & 0.598 & 0.628 & 0.683 & 0.604 & 0.664 & 0.613 & 0.659 & 0.642 \\
\hline $\mathrm{Ca} / \mathrm{K}$ & 6.65 & 6.10 & 7.60 & 6.71 & 6.93 & 6.15 & 6.75 & 7.68 & 6.63 & 6.83 \\
\hline MT-10 biotite & Core & Core & Core & Rim & Rim & Core & Rim & Rim & Core & Core \\
\hline \multicolumn{11}{|l|}{ Wt\% } \\
\hline $\mathrm{SiO}_{2}$ & 35.74 & 35.87 & 35.88 & 36.06 & 35.64 & 36.37 & 36.06 & 35.67 & 35.95 & 36.10 \\
\hline $\mathrm{TiO}_{2}$ & 2.55 & 2.22 & 2.31 & 2.47 & 2.43 & 2.77 & 2.48 & 2.50 & 2.64 & 2.39 \\
\hline $\mathrm{Al}_{2} \mathrm{O}_{3}$ & 15.50 & 15.88 & 15.63 & 15.65 & 15.50 & 15.26 & 15.21 & 14.73 & 14.85 & 15.72 \\
\hline $\mathrm{FeO}$ & 21.28 & 21.97 & 22.22 & 22.02 & 22.17 & 21.64 & 21.95 & 22.30 & 22.30 & 21.83 \\
\hline $\mathrm{MnO}$ & 0.45 & 0.25 & 0.25 & 0.17 & 0.31 & 0.43 & 0.32 & 0.41 & 0.28 & 0.27 \\
\hline $\mathrm{MgO}$ & 10.13 & 9.81 & 9.73 & 9.53 & 9.48 & 9.72 & 9.77 & 9.67 & 9.52 & 9.86 \\
\hline $\mathrm{CaO}$ & 0.00 & 0.04 & 0.00 & 0.05 & 0.00 & 0.00 & 0.00 & 0.00 & 0.00 & 0.00 \\
\hline $\mathrm{Na}_{2} \mathrm{O}$ & 0.05 & 0.02 & 0.06 & 0.02 & 0.00 & 0.02 & 0.00 & 0.05 & 0.02 & 0.02 \\
\hline $\mathrm{K}_{2} \mathrm{O}$ & 9.56 & 9.71 & 9.61 & 9.57 & 9.72 & 9.67 & 9.75 & 9.57 & 9.76 & 9.50 \\
\hline $\mathrm{BaO}$ & 0.20 & 0.25 & 0.17 & 0.13 & 0.16 & 0.24 & 0.29 & 0.08 & 0.08 & 0.08 \\
\hline $\mathrm{H}_{2} \mathrm{O}$ & 3.74 & 3.67 & 3.74 & 3.73 & 3.69 & 3.78 & 3.68 & 3.78 & 3.78 & 3.77 \\
\hline$F$ & 0.26 & 0.29 & 0.15 & 0.17 & 0.19 & 0.22 & 0.34 & 0.02 & 0.12 & 0.22 \\
\hline $\mathrm{Cl}$ & 0.04 & 0.31 & 0.27 & 0.30 & 0.29 & 0.06 & 0.16 & 0.20 & 0.09 & 0.09 \\
\hline total & 99.51 & 100.29 & 100.01 & 99.87 & 99.60 & 100.17 & 100.01 & 98.97 & 99.39 & 99.86 \\
\hline O $1 / 4 \mathrm{~F}$ & 0.11 & 0.12 & 0.06 & 0.07 & 0.08 & 0.09 & 0.14 & 0.00 & 0.05 & 0.09 \\
\hline $\mathrm{O}_{1 / 4} \mathrm{Cl}$ & 0.00 & 0.07 & 0.06 & 0.07 & 0.07 & 0.01 & 0.04 & 0.05 & 0.02 & 0.02 \\
\hline $\begin{array}{l}\text { total O } \\
\text { pfu }\end{array}$ & 99.39 & 100.10 & 99.89 & 99.73 & 99.45 & 100.07 & 99.83 & 98.92 & 99.32 & 99.74 \\
\hline Si & 5.528 & 5.530 & 5.543 & 5.567 & 5.539 & 5.591 & 5.576 & 5.576 & 5.590 & 5.559 \\
\hline $\mathrm{Ti}$ & 0.297 & 0.257 & 0.268 & 0.286 & 0.284 & 0.321 & 0.288 & 0.294 & 0.309 & 0.277 \\
\hline
\end{tabular}

MT-27 constitutes an clinopyroxene that is replaced by amphibolite band in a tonalite. This massive coarse-grained rock virtually lacks deformation fabrics or preferred orientation, but contains cm-thick boudins and isolated fold hinges of intensely deformed plagioclase veins. It comprises moss-green hornblende, plagioclase (with garnet inclusions) and quartz. It contains substantial amounts of salitic hornblende along grain boundaries and parting and cleavage planes. Epidote is a rare constituent; titanite and biotite are absent. Hornblende (>3500 $\mu \mathrm{m}$ in cross section) may show some zoning towards lighter green colours in rims and fractures, as well as around included clinopyroxene relics. EPMA revealed an increasing actinolite component in hornblende toward such lighter coloured zones, yielding lower $\mathrm{K}$, $\mathrm{Na}$ and $\mathrm{Ti}$ contents and much higher $\mathrm{Ca} / \mathrm{K}$ ratios in these areas (Tab. 1; Fig. 3). Actinolite-rich zones are about 5-25 $\mu \mathrm{m}$ wide (Fig. 4), whereas individual actinolite inclusions and newly formed euhedral crystals measure up to $20 \mu \mathrm{m}$. 


\begin{tabular}{|c|c|c|c|c|c|c|c|c|c|c|c|c|c|c|c|}
\hline \multirow{2}{*}{$\frac{\text { MT-10 biotite }}{\mathrm{Al}}$} & \multirow{2}{*}{$\begin{array}{l}\text { Core } \\
2.826\end{array}$} & \multicolumn{2}{|c|}{ Core } & \multirow{2}{*}{$\begin{array}{l}\text { Core } \\
2.845\end{array}$} & \multicolumn{2}{|c|}{ Rim } & \multicolumn{2}{|l|}{ Rim } & Core & \multicolumn{2}{|l|}{ Rim } & Rim & \multicolumn{2}{|c|}{ Core } & Core \\
\hline & & \multicolumn{2}{|c|}{2.885} & & \multicolumn{2}{|c|}{2.848} & \multicolumn{2}{|c|}{2.840} & 2.764 & \multicolumn{2}{|c|}{2.772} & 2.714 & \multicolumn{2}{|c|}{2.722} & 2.852 \\
\hline $\mathrm{Fe}^{2+}$ & 2.752 & \multicolumn{2}{|c|}{2.832} & 2.870 & \multicolumn{2}{|c|}{2.844} & \multicolumn{2}{|c|}{2.882} & 2.781 & 2.83 & & 2.915 & 2.8 & & 2.810 \\
\hline Mn & 0.059 & & .032 & 0.032 & & 0.022 & 0.041 & & 0.055 & 0.04 & & 0.055 & 0.0 & 37 & 0.035 \\
\hline $\mathrm{Mg}$ & 2.336 & & .255 & 2.240 & & 2.195 & 2.198 & & 2.228 & 2.25 & & 2.253 & 2.2 & & 2.263 \\
\hline $\mathrm{Ca}$ & 0.000 & & .007 & 0.000 & & 0.008 & 0.000 & & 0.000 & 0.00 & & 0.000 & 0.0 & 00 & 0.000 \\
\hline $\mathrm{Na}$ & 0.014 & & .005 & 0.018 & & 0.005 & 0.000 & & 0.006 & 0.00 & & 0.014 & 0.0 & 06 & 0.007 \\
\hline K & 1.887 & & 909 & 1.894 & & 1.886 & 1.928 & & 1.896 & 1.92 & & 1.908 & 1.9 & 36 & 1.866 \\
\hline B & 0.012 & & .015 & 0.010 & & 0.008 & 0.010 & & 0.015 & 0.01 & & 0.005 & 0.0 & 05 & 0.005 \\
\hline $\mathrm{OH}$ & 3.864 & & 779 & 3.855 & & 3.837 & 3.831 & & 3.877 & 3.79 & & 3.938 & 3.9 & 19 & 3.869 \\
\hline$F$ & 0.125 & & 140 & 0.074 & & 0.083 & 0.092 & & 0.108 & 0.16 & & 0.008 & 0.0 & 59 & 0.108 \\
\hline $\mathrm{Cl}$ & 0.011 & & .081 & 0.071 & & 0.079 & 0.077 & & 0.015 & 0.04 & & 0.054 & 0.0 & 22 & 0.024 \\
\hline total & 19.713 & 19. & 728 & 19.722 & & 9.668 & 19.721 & & 19.658 & 19.71 & & 19.735 & 19.7 & & 19.675 \\
\hline mg num & 0.459 & & 443 & 0.438 & & 0.436 & 0.433 & & 0.445 & 0.44 & & 0.436 & 0.4 & & 0.446 \\
\hline MT-27 hornblende & Core & Core & $\Leftarrow 70 \mu \mathrm{n}$ & $m$ traverse & & Rim & Rim & Core & Core & Inter & Rim & Incl & Ind & Core & Core \\
\hline$\overline{W t . \%}$ & & & & & & & & & & & & & & & \\
\hline $\mathrm{SiO}_{2}$ & 42.99 & 43.22 & 45.52 & 47.33 & 50.13 & 51.22 & 51.59 & 44.16 & 43.70 & 46.43 & 50.30 & 52.44 & 51.67 & 42.62 & 42.85 \\
\hline $\mathrm{TiO}_{2}$ & 1.47 & 1.44 & 0.72 & 0.72 & 0.29 & 0.18 & 0.21 & 1.33 & 1.48 & 0.80 & 0.28 & 0.19 & 0.14 & 1.96 & 1.65 \\
\hline $\mathrm{Al}_{2} \mathrm{O}_{3}$ & 11.31 & 10.95 & 8.97 & 7.57 & 5.48 & 4.19 & 3.73 & 10.43 & 10.92 & 8.20 & 5.53 & 3.56 & 3.76 & 11.58 & 11.66 \\
\hline $\mathrm{Cr}_{2} \mathrm{O}_{3}$ & 0.12 & 0.00 & 0.04 & 0.00 & 0.00 & 0.08 & 0.00 & 0.05 & 0.06 & 0.01 & 0.00 & 0.06 & 0.09 & 0.12 & 0.00 \\
\hline $\mathrm{Fe}_{2} \mathrm{O}_{3}$ & 5.71 & 6.74 & 5.32 & 4.38 & 1.39 & 3.07 & 2.45 & 5.31 & 2.04 & 5.79 & 2.02 & 2.64 & 1.44 & 1.03 & 1.55 \\
\hline $\mathrm{FeO}$ & 13.04 & 11.94 & 12.67 & 12.73 & 14.03 & 11.38 & 11.54 & 13.16 & 16.16 & 11.85 & 13.10 & 11.67 & 12.53 & 16.94 & 17.08 \\
\hline MnO & 0.34 & 0.30 & 0.28 & 0.16 & 0.23 & 0.32 & 0.30 & 0.33 & 0.36 & 0.28 & 0.21 & 0.27 & 0.35 & 0.30 & 0.31 \\
\hline $\mathrm{MgO}$ & 9.22 & 9.17 & 10.62 & 11.15 & 12.95 & 13.85 & 13.92 & 9.71 & 9.62 & 11.47 & 13.51 & 14.65 & 14.34 & 9.10 & 9.03 \\
\hline $\mathrm{CaO}$ & 12.24 & 12.41 & 12.47 & 12.60 & 12.70 & 12.92 & 14.15 & 12.27 & 12.08 & 12.46 & 12.79 & 12.81 & 12.85 & 11.97 & 12.12 \\
\hline $\mathrm{Na}_{2} \mathrm{O}$ & 1.51 & 1.44 & 0.98 & 0.84 & 0.60 & 0.38 & 0.40 & 1.31 & 1.46 & 0.95 & 0.63 & 0.49 & 0.43 & 1.57 & 1.59 \\
\hline $\mathrm{K}_{2} \mathrm{O}$ & 0.73 & 0.80 & 0.63 & 0.49 & 0.26 & 0.14 & 0.16 & 0.61 & 0.65 & 0.50 & 0.25 & 0.12 & 0.15 & 0.79 & 0.77 \\
\hline $\mathrm{H}_{2} \mathrm{O}$ & 1.93 & 1.97 & 1.97 & 1.99 & 2.00 & 2.05 & 2.06 & 1.96 & 1.97 & 2.02 & 2.05 & 2.05 & 2.04 & 1.99 & 1.96 \\
\hline $\mathrm{F}$ & 0.13 & 0.02 & 0.06 & 0.05 & 0.09 & 0.00 & 0.00 & 0.09 & 0.06 & 0.00 & 0.01 & 0.06 & 0.03 & 0.00 & 0.05 \\
\hline $\mathrm{Cl}$ & 0.00 & 0.02 & 0.00 & 0.02 & 0.02 & 0.00 & 0.00 & 0.00 & 0.00 & 0.00 & 0.01 & 0.00 & 0.02 & 0.00 & 0.05 \\
\hline total & 100.73 & 100.42 & 100.24 & 100.01 & 100.16 & 99.80 & 100.50 & 100.72 & 100.56 & 100.75 & 100.71 & 101.02 & 99.83 & 99.96 & 100.67 \\
\hline $0=F$ & 0.05 & 0.00 & 0.03 & 0.02 & 0.04 & 0.00 & 0.00 & 0.04 & 0.02 & 0.00 & 0.00 & 0.03 & 0.01 & 0.00 & 0.02 \\
\hline $0=\mathrm{Cl}$ & 0.00 & 0.00 & 0.00 & 0.00 & 0.00 & 0.00 & 0.00 & 0.00 & 0.00 & 0.00 & 0.00 & 0.00 & 0.00 & 0.00 & 0.01 \\
\hline total & 100.68 & 100.41 & 100.21 & 99.99 & 100.12 & 99.79 & 100.50 & 100.68 & 100.54 & 100.75 & 100.70 & 100.99 & 99.82 & 99.96 & 100.64 \\
\hline $\begin{array}{l}\text { Felt] as Fe0 } \\
\text { pfu }\end{array}$ & 18.17 & 18.01 & 17.45 & 16.66 & 15.28 & 14.14 & 13.74 & 17.93 & 18.00 & 17.06 & 14.93 & 14.05 & 13.82 & 17.87 & 18.48 \\
\hline $\mathrm{Si}$ & 6.389 & 6.427 & 6.738 & 6.974 & 7.319 & 7.436 & 7.455 & 6.537 & 6.517 & 6.805 & 7.284 & 7.510 & 7.505 & 6.416 & 6.418 \\
\hline $\mathrm{Ti}$ & 0.164 & 0.161 & 0.080 & 0.079 & 0.032 & 0.020 & 0.023 & 0.148 & 0.166 & 0.088 & 0.031 & 0.021 & 0.015 & 0.222 & 0.186 \\
\hline Al & 1.981 & 1.919 & 1.564 & 1.315 & 0.943 & 0.717 & 0.636 & 1.819 & 1.919 & 1.416 & 0.943 & 0.601 & 0.644 & 2.054 & 2.057 \\
\hline $\mathrm{Gr}$ & 0.014 & 0.000 & 0.005 & 0.001 & 0.000 & 0.009 & 0.000 & 0.006 & 0.007 & 0.002 & 0.000 & 0.007 & 0.010 & 0.014 & 0.000 \\
\hline $\mathrm{Fe}^{3+}$ & 0.638 & 0.754 & 0.592 & 0.485 & 0.153 & 0.335 & 0.266 & 0.591 & 0.229 & 0.638 & 0.221 & 0.285 & 0.157 & 0.117 & 0.175 \\
\hline $\mathrm{Fe}^{2+}$ & 1.621 & 1.485 & 1.568 & 1.568 & 1.712 & 1.381 & 1.395 & 1.629 & 2.015 & 1.452 & 1.587 & 1.397 & 1.522 & 2.132 & 2.140 \\
\hline Mn & 0.043 & 0.037 & 0.035 & 0.019 & 0.028 & 0.040 & 0.037 & 0.042 & 0.045 & 0.035 & 0.026 & 0.033 & 0.043 & 0.038 & 0.039 \\
\hline $\mathrm{Mg}$ & 2.043 & 2.032 & 2.343 & 2.450 & 2.818 & 2.998 & 2.998 & 2.143 & 2.139 & 2.506 & 2.916 & 3.126 & 3.104 & 2.041 & 2.016 \\
\hline $\mathrm{Ca}$ & 1.950 & 1.978 & 1.977 & 1.988 & 1.986 & 2.010 & 2.191 & 1.945 & 1.930 & 1.956 & 1.984 & 1.964 & 1.999 & 1.930 & 1.945 \\
\hline $\mathrm{Na}$ & 0.435 & 0.416 & 0.280 & 0.239 & 0.169 & 0.106 & 0.111 & 0.377 & 0.421 & 0.271 & 0.178 & 0.135 & 0.121 & 0.459 & 0.462 \\
\hline K & 0.138 & 0.151 & 0.118 & 0.092 & 0.049 & 0.026 & 0.029 & 0.116 & 0.124 & 0.093 & 0.046 & 0.022 & 0.028 & 0.152 & 0.147 \\
\hline total & 15.416 & 15.359 & 15.301 & 15.211 & 15.209 & 15.079 & 15.141 & 15.353 & 15.512 & 15.262 & 15.215 & 15.101 & 15.149 & 15.575 & 15.584 \\
\hline Al(iv) & 1.611 & 1.573 & 1.262 & 1.026 & 0.681 & 0.564 & 0.545 & 1.463 & 1.483 & 1.195 & 0.716 & 0.490 & 0.495 & 1.584 & 1.582 \\
\hline mg num & 0.558 & 0.578 & 0.599 & 0.610 & 0.622 & 0.685 & 0.682 & 0.568 & 0.515 & 0.633 & 0.648 & 0.691 & 0.671 & 0.489 & 0.485 \\
\hline A site & 0.573 & 0.567 & 0.398 & 0.331 & 0.218 & 0.132 & 0.140 & 0.493 & 0.545 & 0.364 & 0.224 & 0.157 & 0.149 & 0.611 & 0.609 \\
\hline $\mathrm{Ca} / \mathrm{K}$ & 14.13 & 13.10 & 16.75 & 21.61 & 40.53 & 77.31 & 75.55 & 16.77 & 15.56 & 21.03 & 43.13 & 89.27 & 71.39 & 12.70 & 13.23 \\
\hline
\end{tabular}

Analyses made with a Cameca SX50 (School of Earth Sciences, Leeds University), operated at an acceleration voltage of $15 \mathrm{kV}$. Calibration against natural oxides and minerals; accuracy of analyses was tested against a series of well-characterised secondary mineral standards at the start of each session. Mineral formulae calculated on the basis of 22 axygens for biotite and 23 for amphibole. $m g$ num $=\mathrm{Mg}(\mathrm{Mg}+\mathrm{Fe})$. pfu $=$ per formula unit.

Many actinolite-rich zones in hornblende MT-10 and MT-11 contain biotite, but not in MT-27. This shows that biotite was not produced during retrogressive growth of actinolite in hornblende. The confinement of biotite to grain boundaries and lattice imperfections in hornblende implies localised ingress of an aqueous fluid with an increased activity of K-ions. As biotitebearing quartz-feldspar gneisses surrounding the amphibolites are K-richer, the localised hydration implies an open system on at least the scale of several $\mathrm{dm}$ to metres.

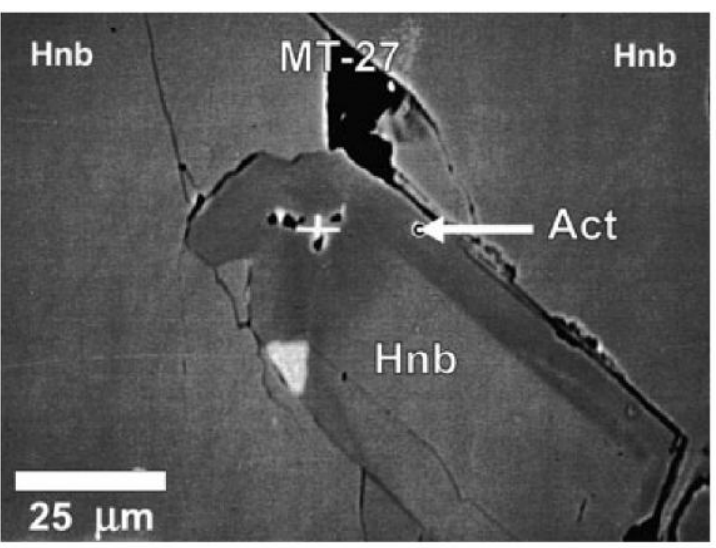

Fig. 4 Back-scatter electron image of a compositionally zoned amphibole from amphibolite MT-27. Arrow indicates electron probe microanalysis \#7 (Table 1) in an 


\section{Experimental Procedures}

Argon isotopes were extracted from hornblende (MT-10, MT-11 and MT-27) and biotite separates by step-heating in a doublevacuum, resistance-heated furnace and measured on an AEI MS10 mass spectrometer at Leeds University. Mineral separates were prepared by handpicking the 75 $100 \mu \mathrm{m}$ size fraction obtained by standard procedures.

Ca. $1.5 \mathrm{~mm}$ diameter discs were drilled from much larger hornblende crystals (MT-11 and MT-27) in polished thin sections and step-heated with a continuous laser. The discs were thoroughly rinsed in acetone and subsequently in distilled water after being

\section{Results}

Furnace step-heating of hornblende separates yielded single, sharp peaks in the $950-1075^{\circ} \mathrm{C}$ range (Tab. 2; Fig. 5). $\mathrm{Cl} / \mathrm{K}$ and $\mathrm{Ca} / \mathrm{K}$ ratios referring to hornblende's main degassing cluster tightly in chemical correlation diagrams (Fig. $6)$.

Hornblende separates MT-10 and MT-11 yielded spectra with progressively increasing $\mathrm{Ca} / \mathrm{K}$ ratios and apparent ages to about $2.6 \mathrm{Ga}$, following an excessively old first increment for the latter sample, also observed for drilled grain MT-11 (Tabs. 2, 3; Figs. 7a, b). The first increment of MT-10 is as young as the youngest biotites of the MT, like MT-11 (Tab. 2; Figs. $7 \mathrm{a}, \mathrm{b}) . \mathrm{Ca} / \mathrm{K}$ ratios of $6-6.5$ for separate $\quad$ MT-10 $\quad\left(970-1085^{\circ} \mathrm{C}\right.$ range) are comparable to values of 6.1-7.7 obtained by EPMA (Tabs. 1, 2; Figs. 3, 7a); they steadily increase during the final $5 \%$ of 39Ar release to values of about 20 . Interestingly, drilled grain MT-11 lacks the staircase-shaped section detached from the thin section glass support. The laserprobe in Amsterdam comprises a Spectra Physics $24 \mathrm{~W}$ argon ion laser and an MAP 215-50 noble gas mass spectrometer. To avoid uneven heating of the discs the laser beam was defocused to a focal distance of 580-590 mm (f:500 achromatic focusing lens) yielding a $c a .2 \mathrm{~mm}$ diameter laser spot that was truncated at the edges with an iris diaphragm to remove the lowenergy halo around the beam.

Samples and neutron flux monitors were irradiated for 30 hours at the ECN/EU research reactor (Petten, Netherlands). Mineral separates in high purity aluminium foil envelopes were loaded into a Spectrosil phial for irradiation. Drilled hornblende discs were directly loaded in holes in a $22 \mathrm{~mm}$ diameter aluminium tray in a $25 \mathrm{~mm}$ OD standard irradiation cans. The $\left({ }^{36} \mathrm{Ar} /{ }^{37} \mathrm{Ar}\right)_{\mathrm{Ca}}$, $\left({ }^{39} \mathrm{Ar} /{ }^{37} \mathrm{Ar}\right)_{\mathrm{Ca}}$ and $\left({ }^{40} \mathrm{Ar} /{ }^{39} \mathrm{Ar}\right)_{\mathrm{K}}$ ratios used in the corrections for $\mathrm{Ca}$ - and K-derived Ar isotopes produced in the unshielded High Flux Pool Side Isotope Facility (HFPIF) are: $0.000273,0.000699$ and 0.06051 , respectively. Flux gradients were about $5 \%$ over the length of the cans and below $0.4 \%$ horizontally within the tray.

Experimental details are given in the footnotes to Tables 2 and 3 with ${ }^{40} \mathrm{Ar} /{ }^{39} \mathrm{Ar}$ analytical data.

and shows slightly decreasing apparent ages to ca. 2.64 Ga instead (Tab. 3; Fig. 7b). Its fairly constant $\mathrm{Ca} / \mathrm{K}$ ratio of about 12 is comparable to ratios of $10-11.5$ of separate MT- 11 above $980^{\circ} \mathrm{C}$ (Tab. 3; Fig. 7b). Trends in $\mathrm{Cl} / \mathrm{K}$ and $\mathrm{Ca} / \mathrm{K}$ ratios of separate MT-10 inversely correlate during the first 95\% of gas release (Fig. 7a). In contrast, separate MT-11 lacks such decreasing $\mathrm{Cl} / \mathrm{K}$ ratios (Fig. $7 \mathrm{~b}$ ). $\mathrm{Cl} / \mathrm{K}$ ratios of drilled grain $\mathrm{MT}-11$ are much lower than those of the separate (Tabs. 2, 3) and unrelated to trends in $\mathrm{Ca} / \mathrm{K}$ ratios (Fig. 7b), which we explain by the small gas volume released by laser step-heating, in which ${ }^{38} \mathrm{Ar}_{\mathrm{Cl}}$ was, apparently, close to the detection limit.

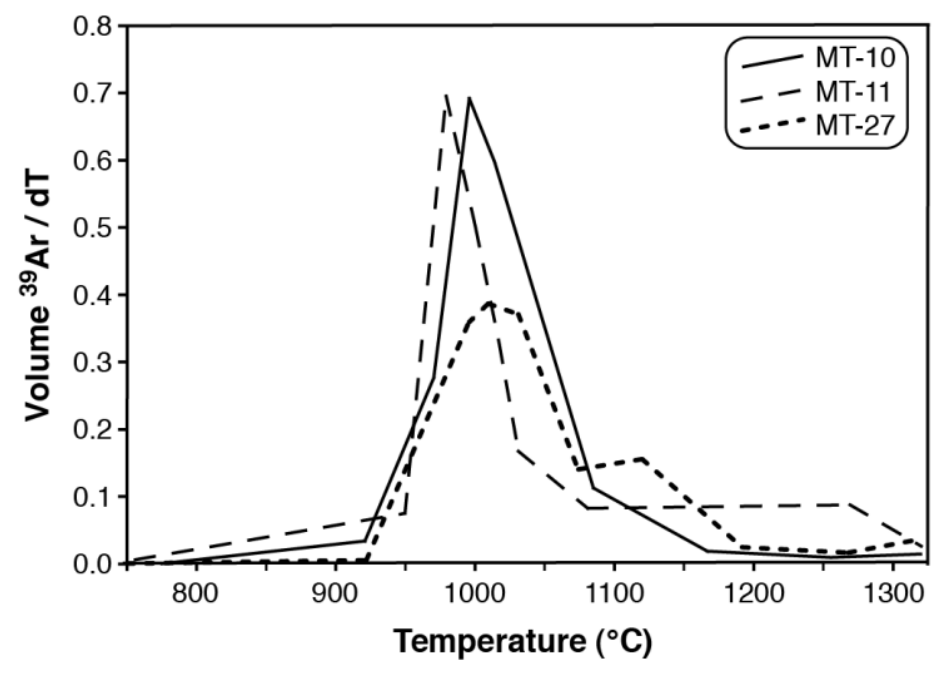

Fig. 5 Differential thermal release of ${ }^{39} \mathrm{Ar}{ }_{K}$ plotted as the gas volume normalized by the temperature intervals between two successive steps vs. temperature during stepheating of hornblende separates with the resistance furnace. The main degassing occurred in single sharp peaks around about $1000^{\circ} \mathrm{C}$. 
Fig. 6 Chemical correlation diagrams displaying $\mathrm{Ca} / \mathrm{K}$ vs. $\mathrm{Cl} / \mathrm{K}$ ratios obtained by resistance furnace step-heating of hornblende separates MT-10 (a), MT-11 (b) and MT-27 (c) (open symbols with degassing temperatures indicated in ${ }^{\circ} \mathrm{C}$ ) and by laser step-heating of drilled hornblende grains MT-11 (b) and MT-27 (c) (filled symbols). Hornblende's main degassing occurred around $1000^{\circ} \mathrm{C}$ with tightly clustered $\mathrm{Ca} / \mathrm{K}$ and $\mathrm{Cl} / \mathrm{K}$ ratios. Increments with deviating apparent ages (in Ma rounded to the closest age) with respect to the age of the main hornblende are indicated in bold between brackets. Mixing lines towards biotite (degassing at lower temperatures) and Ca-rich inclusions (degassing at higher temperatures) indicated by grey arrows. Dotted arrows (c) point toward a Cl-rich composition carrying excess Ar (fluid Dotted arrows (c) point toward a Cl-rich composition carrying excess $\mathrm{Ar}$ (fluid
inclusions?) for hornblende MT-27 both separate (735 ${ }^{\circ} \mathrm{C} ; 4865 \mathrm{Ma}$ and $920{ }^{\circ} \mathrm{C}$; inclusions?) for hornblende MT-27 both separate $\left(735{ }^{\circ} \mathrm{C}\right.$; $4865 \mathrm{Ma}$ and $920{ }^{\circ} \mathrm{C}$; $3242 \mathrm{Ma}$ ) and single grain (first step age: $3152 \mathrm{Ma}$ ). The first furnace step-heating increment MT-11 (b) at $755{ }^{\circ} \mathrm{C}(3360 \mathrm{Ma})$ is probably a mixed degassing of excess $\mathrm{Ar}$ and biotite components, whereas the first laser step-heating increment of the drilled grain carried essentially only an excess Ar component (4403 Ma). Significant difference of integrated Ar/Ar ages for drilled grain and the hornblende separate of MT-11 (Tables 2 and 3) probably point to heterogeneous excess Ar incorporation at the grain scale in this sample. The first biotite-dominated heating increment of MT-10 (a) at $775^{\circ} \mathrm{C}(1827 \mathrm{Ma})$ probably also contains gas released by fluid inclusions, given the elevated $\mathrm{Cl} / \mathrm{K}$ ratio.
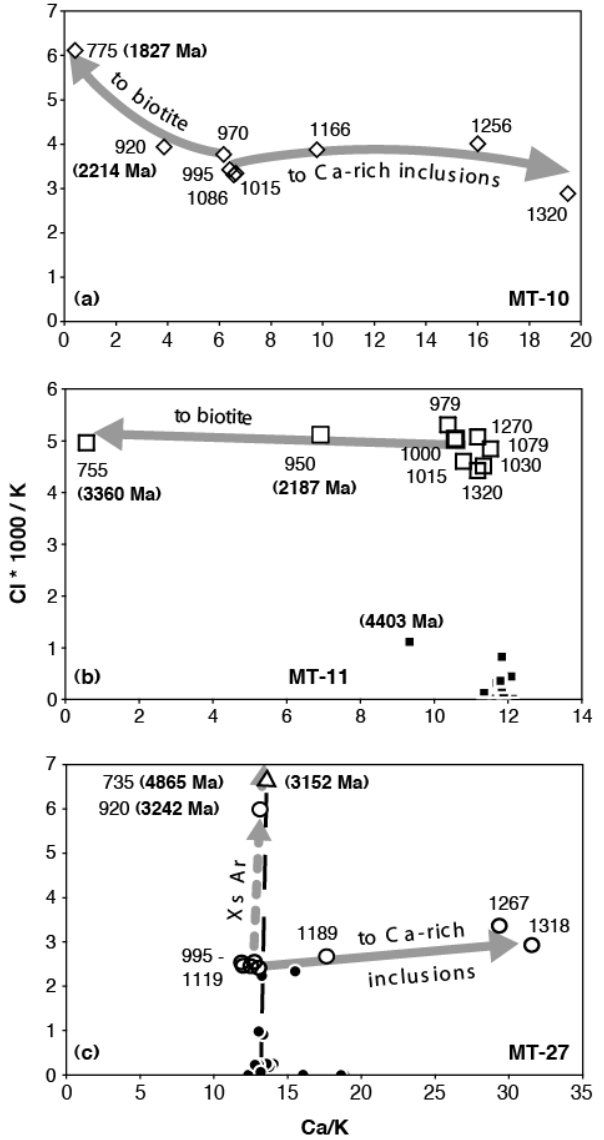

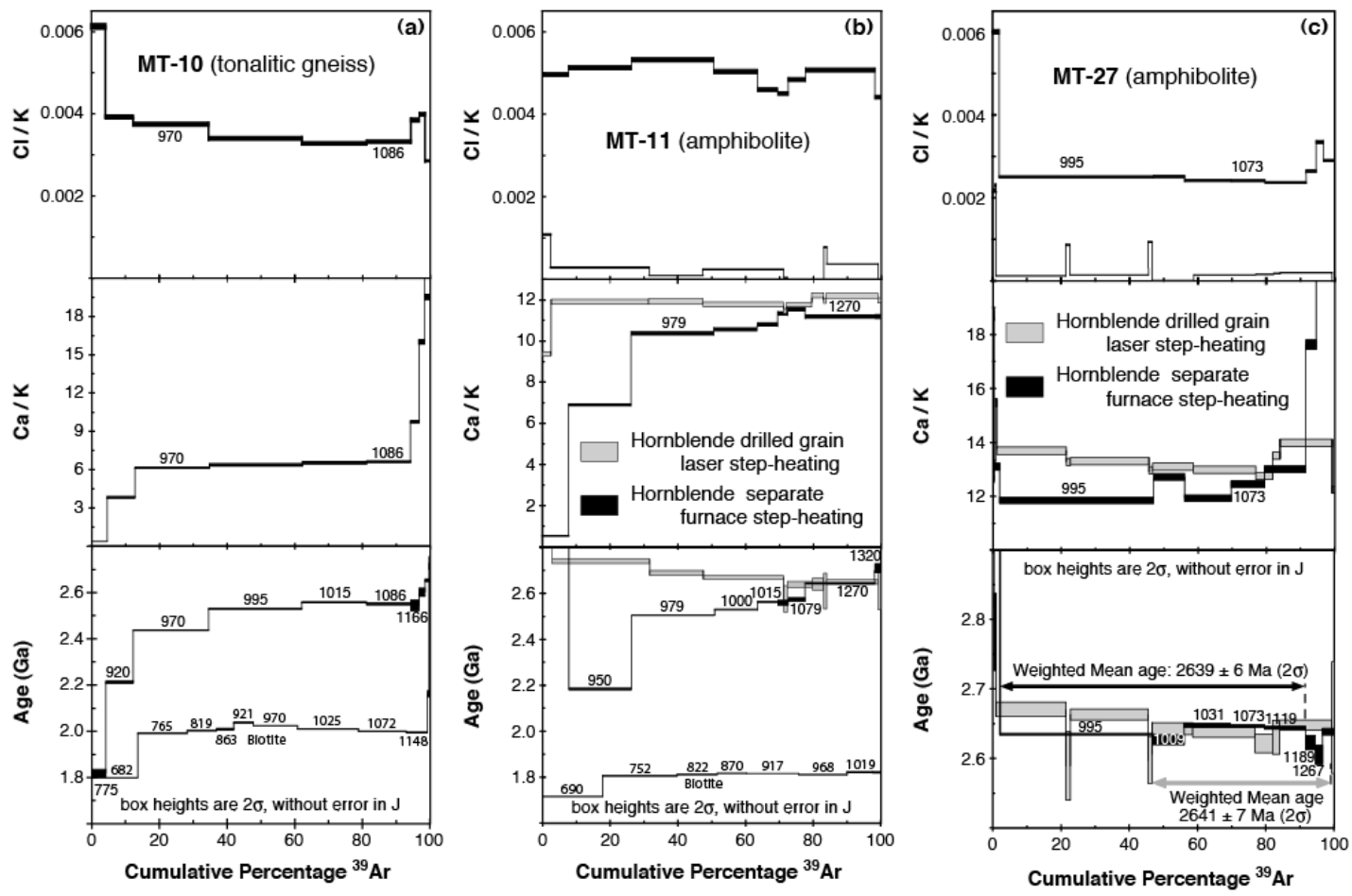

Fig. $7{ }^{40} \mathrm{Ar} /{ }^{39} \mathrm{Ar}$ age spectra (lower panels), $\mathrm{Ca} / \mathrm{K}$ ratio spectra (middle panels) and $\mathrm{Cl} / \mathrm{K}$ ratio spectra (upper panels) of samples MT-10 (a), MT-11 (b) and MT-27 (c) from the Murmansk Terrane, acquired by step-heating of drilled hornblende discs (a, c) with a laser probe and with a resistance-heated furnace on homblende $(a-c)$ and biotite separates $(a, b)$. Degassing temperatures indicated in ${ }^{\circ} \mathrm{C}$; those for biotite are given in italics.

Hornblende separate MT-27 has a fairly flat age spectrum, whereas the drilled grain yielded slightly decreasing step ages from 2.67 to $2.62 \mathrm{Ga}$, following excess argon spikes for the first released gas fractions with high $\mathrm{Cl} / \mathrm{K}$ ratios (Tabs. 2, 3; Fig. 7c). The average mean ages of the final 5 steps of the drilled grain $(2641 \pm 7 \mathrm{Ma})$ and of the main increments of the separate $(2639 \pm 6 \mathrm{Ma})$ are concordant. The similar $\mathrm{Ca} / \mathrm{K}$ ratios for separate (1212.5) and drilled grain (13-14), which are fairly constant over the entire ${ }^{39} \mathrm{Ar}$ release (Tabs. 2, 3; Fig. 7c), agree with values of 13-14 obtained by EPMA (Tab. 1; Fig. 3b). $\mathrm{Ca} / \mathrm{K}$ ratios steadily increase for the separate during final $10 \%$ of degassing, but remain constant for the drilled grain (Fig. 7c). The $\mathrm{Cl} / \mathrm{K}$ ratios of separate MT-27 and the much lower values for the drilled grain and are essentially constant and unrelated to trends in $\mathrm{Ca} / \mathrm{K}$ ratios (Tabs. 2 and 3, Fig. 7c). 
Table $2{ }^{40} \mathrm{Ar} /{ }^{39} \mathrm{Ar}$ analytical data of resistance-heated fumace step-heating of hornblende and biotite from the Murmansk Terrane

\begin{tabular}{|c|c|c|c|c|c|c|c|c|c|c|}
\hline \multirow[b]{2}{*}{ Temperature $\left({ }^{\circ} \mathrm{C}\right)$} & \multicolumn{4}{|c|}{ Vol $\left(10^{0} \mathrm{~cm}^{3} \mathrm{STP}\right)$} & \multicolumn{4}{|c|}{ Values (\%) } & \multirow[b]{2}{*}{ Age (Ma) } & \multirow[b]{2}{*}{ Error $(2 r)$} \\
\hline & ${ }^{30} \mathrm{Ar}$ & ${ }^{37} \mathrm{Arca}$ & ${ }^{38} \mathrm{Aral}$ & ${ }^{40} \mathrm{~A} r_{\text {Atm }}$ & $\mathrm{Ca} / \mathrm{K}$ & $\mathrm{Cl} / \mathrm{K}$ & ${ }^{40} \mathrm{Ar}=/{ }^{30} \mathrm{Ark}$ & ${ }^{30} \mathrm{Ar}_{\mathrm{K}}$ & & \\
\hline \multicolumn{11}{|l|}{ MT-10 } \\
\hline Hornblende & \multicolumn{3}{|c|}{ Welght (g): 0.01085} & \multicolumn{3}{|c|}{ J-value: $0.0668 \pm 0.0005$} & \multicolumn{2}{|c|}{ K-Ar age: $2498 \pm 75 \mathrm{Ma}$} & & $\%$ GK: $1.612 \dagger$ \\
\hline 775 & 2.575 & 0.556 & 0.068 & 7.2 & 0.430 & 0.00611 & 26.233 & 4.1 & 1826.6 & 8.2 \\
\hline 920 & 5.176 & 10.084 & 0.088 & 0.7 & 3.877 & 0.00393 & 36.113 & 8.2 & 2214.4 & 2.2 \\
\hline 970 & 13.959 & 43.348 & 0.227 & 0.4 & 6.180 & 0.00376 & 42.768 & 22.2 & 2435.3 & 0.7 \\
\hline 995 & 17.388 & 56.068 & 0.257 & 0.1 & 6.417 & 0.00342 & 45.789 & 27.7 & 2527.3 & 0.7 \\
\hline 1015 & 11.979 & 39.581 & 0.171 & 0.2 & 6.576 & 0.00330 & 46.745 & 19.1 & 2555.5 & 1.2 \\
\hline 1086 & 8.179 & 27.389 & 0.118 & 0.2 & 6.664 & 0.00334 & 46.470 & 13.0 & 2547.4 & 2.4 \\
\hline 1166 & 1.556 & 7.657 & 0.026 & 1.0 & 9.792 & 0.00386 & 46.268 & 2.5 & 2541.5 & 11.3 \\
\hline 1256 & 1.041 & 8.376 & 0.018 & 0.0 & 16.018 & 0.00400 & 48.224 & 1.7 & 2598.2 & 8.7 \\
\hline \multirow[t]{3}{*}{1320} & 0.965 & 9.463 & 0.012 & 0.0 & 19.512 & 0.00288 & 50.038 & 1.5 & 2649.2 & 3.1 \\
\hline & & & & & & & Total gas age & & 2470.6 & 19.0 \\
\hline & \multicolumn{10}{|c|}{${ }^{40} \mathrm{Ar}{ }^{30} \mathrm{Ar}_{\mathrm{K}}{ }^{1 / 4} 43.907 ;{ }^{40} \mathrm{Ar} \cdot 1 / 42542.07 \cdot 10^{17} \mathrm{~cm}^{3} \mathrm{~g}^{1} ; \mathrm{K}$ from ${ }^{30} \mathrm{Ar}{ }^{1 / 4} 1.236$ wt\% } \\
\hline Gotite & \multicolumn{3}{|c|}{ Welght $(g): 0.00545$; } & \multicolumn{3}{|c|}{ J-value: $0.0668 \pm 0.0005$} & K-Ar age: & $4 \pm 59 \mathrm{Ma}$ & & $\%(K: 7.326)$ \\
\hline 682 & 26.288 & 0.930 & 0.175 & 1.1 & 0.070 & 0.00154 & 25.804 & 13.7 & 1807.7 & 0.6 \\
\hline 765 & 27.790 & 0.000 & 0.126 & 0.1 & 0.000 & 0.00105 & 30.294 & 14.5 & 1996.2 & 0.5 \\
\hline 819 & 16.658 & 0.370 & 0.065 & 0.0 & 0.044 & 0.00090 & 30.572 & 8.7 & 2007.2 & 0.9 \\
\hline 863 & 9.839 & 0.000 & 0.039 & 0.2 & 0.000 & 0.00092 & 30.750 & 5.1 & 2014.2 & 2.4 \\
\hline 921 & 11.370 & 1.359 & 0.051 & 0.1 & 0.238 & 0.00104 & 31.450 & 5.9 & 2041.7 & 1.0 \\
\hline 970 & 24.894 & 0.194 & 0.111 & 0.0 & 0.016 & 0.00103 & 31.119 & 13.0 & 2028.7 & 0.4 \\
\hline 1025 & 34.327 & 2.779 & 0.160 & 0.0 & 0.161 & 0.00108 & 30.762 & 17.9 & 2014.7 & 1.0 \\
\hline 1072 & 27.281 & 1.615 & 0.105 & 0.0 & 0.118 & 0.00089 & 30.520 & 14.2 & 2005.2 & 0.9 \\
\hline 1148 & 11.880 & 0.019 & 0.036 & 0.1 & 0.003 & 0.00070 & 30.378 & 6.2 & 1999.5 & 1.1 \\
\hline 1272 & 1.204 & 2.916 & 0.006 & 0.0 & 4.821 & 0.00115 & 34.745 & 0.6 & 2165.4 & 6.7 \\
\hline 1340 & 0.238 & 0.011 & 0.002 & 0.0 & 0.089 & 0.00194 & 52.686 & 0.1 & 2721.3 & 13.4 \\
\hline & & & & & & & Total gas age & & 1987.6 & 16.9 \\
\hline & ${ }^{40} \mathrm{Ar} \cdot \mathrm{PO}^{30} \mathrm{~A}$ & 30.078 & $1 / 410$ & $.71 \cdot 10^{\prime}$ & $m^{3} g^{3} ; k f$ & $\mathrm{~m}^{30} \mathrm{Ar} 1 / 47$ & 13 wt\% & & & \\
\hline MT-11 & & & & & & & & & & \\
\hline Hornblende & Welght & 0.01945 & & J-value: & $0662 \pm 0.0$ & & K-Ar age: & $2 \pm 79$ & & \%K: 0.838 \\
\hline 755 & 6.341 & 1.816 & 0.136 & 2.2 & 0.570 & 0.00496 & 82.159 & 7.7 & 3359.9 & 3.0 \\
\hline 950 & 15.276 & 53.057 & 0.338 & 1.9 & 6.912 & 0.00512 & 35.666 & 18.5 & 2187.1 & 2.3 \\
\hline 979 & 20.293 & 105.759 & 0.466 & 0.6 & 10.371 & 0.00531 & 45.466 & 24.5 & 2505.5 & 0.8 \\
\hline 1000 & 10.616 & 56.382 & 0.231 & 1.0 & 10.569 & 0.00503 & 46.311 & 12.8 & 2530.5 & 1.3 \\
\hline 1015 & 4.977 & 26.988 & 0.099 & 1.5 & 10.792 & 0.00460 & 47.448 & 6.0 & 2563.5 & 1.7 \\
\hline 1030 & 2.564 & 14.604 & 0.050 & 3.6 & 11.334 & 0.00451 & 47.337 & 3.1 & 2560.3 & 5.8 \\
\hline 1079 & 4.152 & 24.049 & 0.087 & 2.9 & 11.527 & 0.00484 & 47.769 & 5.0 & 2572.8 & 4.2 \\
\hline 1270 & 17.044 & 95.717 & 0.374 & 2.4 & 11.176 & 0.00507 & 50.319 & 20.6 & 2644.5 & 0.7 \\
\hline 1320 & 1.516 & 8.519 & 0.029 & 20.1 & 11.179 & 0.00442 & 52.697 & 1.8 & 2708.9 & 10.3 \\
\hline & & & & & & & Total gas age & & 2579.4 & 19.4 \\
\hline & ${ }^{40} \mathrm{Ar} \cdot \mathrm{PO}^{20} \mathrm{~A}$ & $1 / 448.001 ;$ & $A r * 1 / 420$ & 90. $10^{7} 7$ & g) '; K fro & ${ }^{30} \mathrm{Ar} 1 / 40.9$ & wt\% & & & \\
\hline Eottle & Welght & 0.00900 & & J-value: & $0661 \pm 0.0$ & & K-Ar age: & $9 \pm 55 \mathrm{Ma}$ & & \%K: $7.254 \dagger$ \\
\hline 690 & 61.950 & 0.322 & 1.186 & 1.5 & 0.010 & 0.00443 & 24.158 & 17.6 & 1721.6 & 0.3 \\
\hline 752 & 78.005 & 0.216 & 1.386 & 0.1 & 0.006 & 0.00411 & 26.146 & 22.1 & 1810.7 & 0.4 \\
\hline 822 & 42.043 & 0.115 & 0.749 & 0.3 & 0.005 & 0.00412 & 26.289 & 11.9 & 1816.9 & 0.5 \\
\hline 870 & 30.851 & 0.195 & 0.556 & 0.4 & 0.013 & 0.00417 & 26.405 & 8.8 & 1822.0 & 0.6 \\
\hline 917 & 54.299 & 0.359 & 0.967 & 0.2 & 0.013 & 0.00412 & 26.390 & 15.4 & 1821.4 & 0.5 \\
\hline 968 & 50.315 & 0.559 & 0.891 & 0.1 & 0.022 & 0.00409 & 26.289 & 14.3 & 1817.0 & 0.5 \\
\hline 1019 & 26893 & 1.907 & 0.479 & 0.0 & 0.141 & 0.00412 & 26.714 & 7.6 & 1835.4 & 1.2 \\
\hline 1100 & 6.659 & 0.762 & 0.114 & 0.1 & 0.227 & 0.00396 & 27.077 & 1.9 & 18509 & 2.8 \\
\hline 1235 & 0.841 & 0.247 & 0.018 & 15.0 & 0.579 & 0.00495 & 20.507 & 0.2 & 1545.7 & 32.7 \\
\hline 1325 & 0.627 & 0.000 & 0.014 & 25.0 & 0.000 & 0.00516 & 9.582 & 0.2 & 885.2 & 48.4 \\
\hline & & & & & & & Total gas age & & 1800.5 & 11.5 \\
\hline & ${ }^{40} \mathrm{Ar} \cdot \beta^{30} \mathrm{~A}$ & 25.912 ; & * $1 / 410$ & 15. $10^{77}$ & $g^{\prime} ;: \mathrm{K} \mathrm{fr}$ & ${ }^{\circ} \mathrm{Ar} 1 / 48.45$ & wt\% & & & \\
\hline MT-27 & & & & & & & & & & \\
\hline Hornblende & Welght & 0.02143 & & J-value: & $0616 \pm 0.0$ & & K-Ar age: & $34 \pm 79+\mathrm{Ma}$ & & $\mathscr{q K K}: 0.327 \dagger$ \\
\hline 735 & 0.079 & 2.611 & 0.050 & 26.7 & 66.095 & 0.14634 & 224.455 & 0.1 & 4864.6 & 47.4 \\
\hline 920 & 1.081 & 7.123 & 0.028 & 2.6 & 13.119 & 0.00599 & 81.667 & 1.8 & 3241.7 & 5.7 \\
\hline 995 & 26.991 & 161.091 & 0.296 & 0.3 & 11.877 & 0.00254 & 53.731 & 45.1 & 2635.6 & 0.6 \\
\hline 1009 & 5.433 & 34.794 & 0.060 & 0.8 & 12.745 & 0.00255 & 53.413 & 9.1 & 2627.4 & 3.3 \\
\hline 1031 & 8.163 & 49.068 & 0.087 & 0.6 & 11.962 & 0.00246 & 54.218 & 13.7 & 2648.1 & 1.5 \\
\hline
\end{tabular}




\begin{tabular}{|c|c|c|c|c|c|c|c|c|c|c|}
\hline \multirow[b]{2}{*}{ Temperature $\left({ }^{\circ} \mathrm{C}\right)$} & \multicolumn{4}{|c|}{ Vol $\left(10^{-9} \mathrm{~cm}^{3}\right.$ STP $)$} & \multicolumn{4}{|c|}{ Values (\%) } & \multirow[b]{2}{*}{ Age (Ma) } & \multirow[b]{2}{*}{ Error $(2 \theta)$} \\
\hline & ${ }^{39} \mathrm{Ar}_{\mathrm{K}}$ & ${ }^{37} \mathrm{Ar}_{\mathrm{Ca}}$ & ${ }^{38} \mathrm{Ar}_{\mathrm{a}}$ & ${ }^{40} \mathrm{Ar}_{\mathrm{Pam}}$ & $\mathrm{Ca} / \mathrm{K}$ & $\mathrm{Cl} / \mathrm{K}$ & ${ }^{40} \mathrm{Ar}^{*} / 39 \mathrm{Ar}_{\mathrm{K}}$ & ${ }^{39} \mathrm{Ar}_{\mathrm{r}_{\mathrm{K}}}$ & & \\
\hline 1073 & 5.943 & 37.294 & 0.063 & 0.4 & 12.489 & 0.00245 & 54.196 & 9.9 & 2647.6 & 1.0 \\
\hline 1119 & 7.183 & 47.025 & 0.075 & 0.3 & 13.029 & 0.00241 & 54.086 & 12.0 & 2644.7 & 1.0 \\
\hline 1189 & 1.727 & 15.29 & 0.020 & 1.0 & 17.628 & 0.00268 & 53.276 & 2.9 & 2623.8 & 5.2 \\
\hline 1267 & 1.305 & 19.236 & 0.019 & 0.5 & 29.342 & 0.00837 & 52.598 & 2.2 & 2606.1 & 6.7 \\
\hline \multirow[t]{2}{*}{1318} & 1.893 & 29.992 & 0.024 & 0.0 & 31.529 & 0.00293 & 53.871 & 3.2 & 2639.2 & 2.4 \\
\hline & & & & & & & Total gas age & & 2656.7 & 19.6 \\
\hline
\end{tabular}

The furnace temperature was monitored with a Minoltaland ${ }^{\mathrm{N} N} \mathrm{Cyclops} 52$ infra red optical pyrometer and is estimated to be accurate $\mathrm{b} \pm 25{ }^{\circ} \mathrm{C}$ with reproducbility of $\pm 5{ }^{\circ} \mathrm{C}$. Atmospheric argan extraction blanks ranged from $5 \times 10^{-9} \mathrm{~cm}^{340} \mathrm{Ar}$ STP up to $660^{\circ} \mathrm{C}$ through $3 \times 10^{-10}$ at $900{ }^{\circ} \mathrm{C}$ and $2 \times 10^{-9}$ at $1350{ }^{\circ} \mathrm{C}$. ${ }^{40} \mathrm{Av} \mathrm{v}^{\star}$ is radiogenic argan from natural $\mathrm{K}$-decay, ${ }^{40} \mathrm{Arasm}_{\text {is }}$ atmospheric ${ }^{40} \mathrm{Ar} ;{ }^{37} \mathrm{Arca},{ }^{38} \mathrm{Ara}$, and ${ }^{39} \mathrm{Ark}$ are $\mathrm{Ca}$-, $\mathrm{Cl}$ - and $\mathrm{K}$-denived Ar during irradiation. The volume of ${ }^{39} \mathrm{Ark}$ is based on a mass spectrometer sensitivity of $1.4 \times 10^{-7} \mathrm{~V} \mathrm{~cm}^{-3}$ STP. Errors quoted at the $2 \sigma$ level; step erros include analytical uncertainties anly; errors on integrated ages include the uncertainty in the irradiation parameter J and the age of the used flux manitors (biotite Tinto; K.Ar age: $415 \pm 13 \mathrm{Ma}$ (Rex and Guise, 1986); homblende HB3gr; K-Ar age: $1072 \pm 11 \mathrm{Ma}$ (Turner et al., 1971)). Mass spectrometer discrimination d1 =1.0232 measured from analysis of air Ar. For further analytical details at Leeds University, see de Jong et al. (2000). Decay constant and isotopic abundance ratios used ${ }^{40} \mathrm{~K}_{\operatorname{sot}}=5.543 \times 10^{-10} \mathrm{a}^{-1} ;{ }^{40} \mathrm{~K} / \mathrm{K}=$ 0.01167 atom\% (Steiger and läger, 1977).

†Data obtained by D. C. Rex and R. Green (Leeds University).

Table $3{ }^{40} \mathrm{Ar} /{ }^{39} \mathrm{Ar}$ analytical data of laser step-heating of drilled hornblende discs from the Murmansk Terrane

\begin{tabular}{|c|c|c|c|c|c|c|c|c|c|c|c|}
\hline Laser power $(W)$ & ${ }^{36} \mathrm{Ar}_{\mathrm{Atm}}$ & ${ }^{37} \mathrm{Ar}_{\mathrm{Ca}}$ & ${ }^{38} \mathrm{Ara}_{\mathrm{a}}$ & ${ }^{39} \mathrm{Ar}_{\mathrm{K}}$ & ${ }^{40} \mathrm{Ar}_{\mathrm{Cos}}(\%)$ & $\mathrm{Ca} / \mathrm{K}$ & $\mathrm{Cl} / \mathrm{K} \times 1000$ & ${ }^{\infty} \mathrm{Ar}^{*} i^{39} \mathrm{Ar}_{\mathrm{K}}$ & ${ }^{39} \mathrm{Ar}_{\mathrm{k}}(\%)$ & Age (Ma) & Error \\
\hline MT-11 & \multicolumn{11}{|c|}{ J-value: $0.02170 \pm 0.00004$} \\
\hline 1.00 & 0.0008 & 0.1651 & 0.0002 & 0.0359 & 17.5852 & 9.38 & 1.13 & 482.9756 & 2.6 & 4403.1 & 11.7 \\
\hline 1.07 & 0.0004 & 2.3401 & 0.0006 & 0,4018 & 66.0977 & 11.89 & 0.35 & 164.2120 & 28.9 & 2738.7 & 4.7 \\
\hline 1.13 & 0.0002 & 1.3016 & 0.0001 & 0.2226 & 35.3428 & 11.93 & 0.15 & 158.4846 & 16.0 & 2688.9 & 5.0 \\
\hline 1.20 & 0.0004 & 1.9054 & 0.0004 & 0.3305 & 51.7485 & 11.77 & 0.30 & 156.2770 & 23.8 & 2669.3 & 3.7 \\
\hline 1.25 & 0.0001 & 0.0832 & 0.0000 & 0.0148 & 2.2086 & 11.44 & 0.10 & 145.9773 & 1.1 & 2575.1 & 28.8 \\
\hline 1.40 & 0.0001 & 0.5901 & 0.0000 & 0.1025 & 15.7143 & 11.75 & 0.00 & 152.8660 & 7.4 & 2638.7 & 6.5 \\
\hline 1.65 & 0.0000 & 0.2873 & 0.0000 & 0.0480 & 7.3509 & 12.21 & 0.00 & 152.9967 & 3.5 & 2639.8 & 12.1 \\
\hline 2.33 & 0.0000 & 0.0696 & 0.0000 & 0.0119 & 1.7811 & 11.94 & 0.83 & 149.7022 & 0.9 & 2609.7 & 38.7 \\
\hline 3.90 & 0.0001 & 1.2697 & 0.0004 & 0.2126 & 32.8123 & 12.19 & 0.43 & 154.1314 & 15.3 & 2650.1 & 4.6 \\
\hline \multirow[t]{2}{*}{ fsn } & 0.0001 & 0.0625 & 0.0000 & 0.0107 & 1.6298 & 11.97 & 0.00 & 149.7810 & 0.8 & 2610.5 & 40.8 \\
\hline & & & & & & & & Total gas age & & 2732.6 & 17.0 \\
\hline MT-27 & \multicolumn{11}{|c|}{ J-value: $0.02156 \pm 0.00004$} \\
\hline 0.30 & 0.0001 & 0.0042 & 0.0001 & 0.0005 & 0.1346 & 17.61 & 54.21 & 219.7101 & 0.0 & 3151.6 & 6073 \\
\hline 0.65 & 0.0000 & 0.0050 & 0.0000 & 0.0006 & 0.2013 & 16.03 & 0.00 & 297.6114 & 0.0 & 3614.8 & 369.6 \\
\hline 0.80 & 0.0001 & 0.0039 & 0.0000 & 0.0004 & 0.2272 & 18.76 & 0.00 & 474.4371 & 0.0 & 4363.1 & 397.2 \\
\hline 0.93 & 0.0001 & 0.0170 & 0.0000 & 0.0019 & 0.4068 & 18.71 & 0.00 & 204.0287 & 0.1 & 3042.0 & 169.9 \\
\hline 1.00 & 0.0000 & 0.0052 & 0.0000 & 0.0008 & 0.1145 & 12.65 & 0.00 & 136.8969 & 0.0 & 2479.0 & 468.0 \\
\hline 1.01 & 0.0000 & 0.0896 & 0.0001 & 0.0138 & 2.3653 & 13.22 & 2.24 & 170,4278 & 0.6 & 2782.1 & 27.4 \\
\hline 1.15 & 0.0000 & 0.0105 & 0.0000 & 0.0014 & 0.2237 & 15.50 & 2.35 & 161.9431 & 0.1 & 2710.1 & 309.5 \\
\hline 1.25 & 0.0002 & 3.2372 & 0.0004 & 0.4819 & 75.9582 & 13.71 & 0.19 & 157.5150 & 20.6 & 2671.3 & 5.2 \\
\hline 1.30 & 0.0000 & 0.1740 & 0.0001 & 0.0267 & 3.9700 & 13.30 & 0.93 & 148.6086 & 1.1 & 2590.7 & 24.5 \\
\hline 1.37 & 0.0003 & 3.5109 & 0.0005 & 0.5376 & 84.3151 & 13.33 & 0.21 & 156.6673 & 23.0 & 2663.8 & 3.8 \\
\hline 1.42 & 0.0000 & 0.1820 & 0.0001 & 0.0286 & 4.2701 & 13.00 & 1.00 & 149.4649 & 1.2 & 2598.6 & 16.9 \\
\hline 1.50 & 0.0002 & 1.8062 & 0.0001 & 0.2807 & 43.3815 & 13.13 & 0.08 & 154.3957 & 12.0 & 2643.5 & 4.3 \\
\hline 1.60 & 0.0001 & 2.7226 & 0.0004 & 0.4270 & 65.7137 & 13.01 & 0.21 & 153.8012 & 18.2 & 2638.1 & 3.4 \\
\hline 1.70 & 0.0001 & 0.7581 & 0.0001 & 0.1211 & 18.4442 & 12.78 & 0.23 & 152.0842 & 5.2 & 2622.6 & 6.7 \\
\hline 2.00 & 0.0000 & 0.3205 & 0.0001 & 0.0483 & 7.3977 & 13.53 & 0.25 & 153.0406 & 2.1 & 2631.3 & 12.2 \\
\hline 2.85 & 0.0003 & 2.4578 & 0.0004 & 0.3580 & 55.5636 & 14.01 & 0.26 & 154.9836 & 15.3 & 2648.8 & 3.6 \\
\hline \multirow[t]{2}{*}{ fsn } & 0.0000 & 0.0693 & 0.0000 & 0.0115 & 1.7993 & 12.27 & 0.00 & 156.1603 & 0.5 & 2659.3 & 40.0 \\
\hline & & & & & & & \multicolumn{3}{|c|}{ Total gas age } & 2659.7 & 16.6 \\
\hline
\end{tabular}

Data obtained with a defocussed laser; fusion ( $\mathrm{fsn}$ ) for the final step is achieved by beam focusing. ${ }^{40} \mathrm{Av}^{\star}$ is radiogenic argon from natural $\mathrm{K}$-decay; ${ }^{40} \mathrm{Ar}_{\mathrm{cet}}$ is $\omega_{\mathrm{irrected}}$ atmospheric ${ }^{40} \mathrm{Ar} ;{ }^{37} \mathrm{Arca}{ }^{38} \mathrm{Ara}$, and ${ }^{39} \mathrm{Ark}$ are Ca-, Cl- and K-derived Ar during irradiation. The system sensitivity is $1.8( \pm 0.2) \times 10^{17}$ moles/mV. System blank values were determined at the beginning of an experiment and typically after each 5 th step, and were subtracted from subsequent sample results. Errors quoted at the $2 \sigma$ level; step errors include analytical uncertainties only; errors on integrated ages indude the uncertainty in the irradiation parameter J and the age of the used flux monitor (biotite GA 1550, K-Ar age: $97.9 \pm 0.5 \mathrm{Ma}$ (McDougall and Roksandic, 1974)). Further analytical details at Vrije Universiteit (Amsterdam) are given by Wijprans et al. (1995). Mass spectrometer discriminatan d1 $=1.0099$ measured from analysis of air Av. Decay constant and isotopic abundance ratios used: ${ }^{40} \mathrm{~K}$ sot $=$ $5.543 \times 10^{-10} \mathrm{a}^{-1} ;{ }^{40} \mathrm{KK}=0.01167$ atam\% (Steiger and läger, 1977).

\section{Interpretation of the spectra}

We have obtained flat as well as staircase-shaped ${ }^{40} \mathrm{Ar} /{ }^{39} \mathrm{Ar}$ age spectra for closely spaced samples, which would imply sharply contrasting thermal histories when classically interpreted by thermally activated ${ }^{40} \mathrm{Ar} *$ loss by solid-state volume diffusion. The finding of a flat age spectrum for drilled hornblende MT-11 and an apparent partial loss spectrum for the hornblende separate of this sample shows that such an interpretation is unrealistic.
The similarity of $\mathrm{Ca} / \mathrm{K}$ ratios obtained from EPMA and ${ }^{40} \mathrm{Ar} /{ }^{39} \mathrm{Ar}$ analysis shows that the age information contained in the spectra of drilled grains and separates for the main degassing above $970^{\circ} \mathrm{C}$ refers essentially to hornblende. However, the low $\mathrm{Ca} / \mathrm{K}$ ratios of hornblende 
separates MT-10 and MT-11 for gas release below $970^{\circ} \mathrm{C}$ point to degassing of included K-rich phases, like the observed tiny biotite crystals that occur intergrown in the amphibole. The main degassing of biotite took place below $1000^{\circ} \mathrm{C}$ (Tab. 2; Figs. 7a, b). This interpretation corroborates work by authors who argued that typical partial loss age spectra of hornblende stem from small amounts of incorporated biotite (Berger, 1975; Rex et al., 1993; Lo and Onstott, 1995). The finding of spectra with fairly constant apparent ages and $\mathrm{Ca} / \mathrm{K}$ ratios for hornblende grain MT-11, from which biotite inclusions could be avoided by well targeted drilling, agrees with this interpretation. The fairly constant age and $\mathrm{Ca} / \mathrm{K}$ ratio spectra of biotite-free hornblende MT-27 further strengthen this explanation.

The Ca-rich component that degasses above $1119^{\circ} \mathrm{C}$ during the final $5-10 \%$ of ${ }^{39} \mathrm{Ar}$ release of hornblende separates MT-10 and
MT-27 (Tab. 2; Fig. 7a, c) is unlikely to be apatite as its characteristic elevated $\mathrm{Cl} / \mathrm{K}$ ratio (Belluso et al. 2000) is lacking. Despite its $\mathrm{Ca} / \mathrm{K}$ ratio above 40 (EPMA Tab. 1; Fig. 3b) actinolite is not a good candidate either as it likely degasses well below $1100^{\circ} \mathrm{C}$ (Villa et al. 2000). Hence, clinopyroxene (K-content below detection limit EPMA) and omnipresent in MT-27 may explain the elevated $\mathrm{Ca} / \mathrm{K}$ ratio during the final degassing. Given the constant $\mathrm{Ca} / \mathrm{K}$ ratios (Tab. 3; Fig. 7c), drilled grain MT-27 does not contain this component, in line with the drilling of pristine hornblende. Even for the hornblende separates the influence of these $\mathrm{K}$-poor inclusions is minor as degassing occurred in a narrow peak (Fig. 5) instead of a broad temperature interval that would have chartacterised a multicomponent amphibole separate as outlined by (Villa et al. 2000). This interpretation agrees with tight clustering of $\mathrm{Cl} / \mathrm{K}$ and $\mathrm{Ca} / \mathrm{K}$ ratios of hornblende (Fig. 6).

\section{Conclusions}

Our well-documented natural example has shown that apparent partial loss ${ }^{40} \mathrm{Ar} /{ }^{39} \mathrm{Ar}$ age spectra of hornblende stem from the presence of only minor quantities of intimately intergrown younger biotite that degas before the amphibole host during furnace step-heating experiments. Laser step-heating of hornblende discs microsampled with a microscopemounted drill from parts of grains without biotite and other inclusions, yielded flat age and $\mathrm{Ca} / \mathrm{K}$ ratio spectra.

The significant $c a .2640$

Ma age of hornblende MT-27 has no direct bearing on the age of the peak metamorphism in the MT because the mineral was formed by retrogressive hydration of older metamorphic clinopyroxene. Instead, the data constrain the cooling of the rocks following hornblende formation.

\section{Acknowledgements}

KdJ received salary support from the EC Commission, while being based at Leeds University, UK, as part of the Human Capital and Mobility Network (ERBCHRXC-T940545) on "Major shear zones and crustal boundaries in the Baltic Shield" coordinated by J.S. Daly (University College Dublin, Ireland). KdJ also acknowledges travel grants of the European Science Foundation to Svekalapko Workshops. Two anonymous reviewers and the Associate Editor supplied insightful remarks. Comments on an earlier draft by Bob Cliff, Stephen Daly, Martin Timmerman and Chris Adams are acknowledged and helped to clarify our way of thinking. Dr Felix Mitrofanov and staff of the Kola Science Centre provided logistic support for the fieldwork, for which we are grateful. Martin Timmerman and Victor Balagansky are thanked for help during sampling and many discussions on the Lapland-Kola Orogen. Finally, we would like to thank the following staff of Leeds University: Rodney Green for the K-analysis; Dave Rex and Phil Guise for keeping the Argon lab up and running; Tom Oddy and Gary Keech for mineral separation and Eric Condliffe for assistance with EPMA. This paper is a contribution to the Europrobe SVEKALAPKO project <http://www.gf.oulu.fi/Svekalapko.html>. 


\section{References}

Ahn, J.H., and Cho, M., 1998. Submicroscopic alteration of hornblende in the amphibolitic schists, northwestern Okchon metamorphic belt. Geoscience Journal, 2, 165-174.

Balagansky, V.V., Timmerman, M.J., Kozlova, N.Ye. and Kislitsyn, R.V., 2001. A 2.44 Ga syn-tectonic mafic dyke swarm in the Kolvitsa Belt, Kola Peninsula, Russia: implications for early Palaeoproterozoic tectonics in the north-eastern Fennoscandian Shield. Precambrian Research, 105, 269-287.

Balashov, Y.A., Mitrofanov, F.P. and Balagansky, V.V., 1992. New geochronological data on Archaean rocks of the Kola Peninsula. In: Correlation of Precambrian formations of the Kola-Karelian region and Finland (V.V. Balagansky and F.P. Mitrofanov, eds.), pp. 13-34. Kola Science Centre, Apatity.

Baldwin, S.L., Harrison, T.M. and Fitz Gerald, J.D., 1990. Diffusion of ${ }^{40} \mathrm{Ar}$ in metamorphic hornblende. Contributions to Mineralogy and Petrology, 105, 691-703.

Batiyeva, I.D. and Bel'kov, I.V., 1968. Granitoid formations of the Kola Peninsula. In: Profiles of petrology, mineralogy and metallogeny of the Kola Peninsula. pp. 5-143. Nauka, Leningrad (in Russian).

Belluso, E., Ruffini, R., Schaller, M., and Villa, I.M., 2000. Electron-microscope and Ar-isotope characterization of chemically heterogeneous amphiboles from the Palala Shear Zone, Limpopo Belt, South Africa. European Journal of Mineralogy, 12, 45-62.

Berger, G.W., 1975. ${ }^{40} \mathrm{Ar} /{ }^{39} \mathrm{Ar}$ step heating of thermally overprinted biotite, hornblende and potassium feldspar from Eldora, Colorado. Earth and Planetary Science Letters, 26, 387-408.

Berry, R.F. and McDougall, I., 1986. Interpretation of ${ }^{40} \mathrm{Ar} /{ }^{39} \mathrm{Ar}$ and $\mathrm{K}-\mathrm{Ar}$ dating evidence from the Aileu formation, East Timor, Indonesia. Chemical Geology, 59, 43-58.

von Blanckenburg, F., and Villa, I.M., 1988. Argon retentivity and argon excess in amphiboles from the garbenschists of the Western Tauern Window, Eastern Alps. Contributions to Mineralogy and Petrology, 100, 1-11.

Bridgwater, D., Scott, D.J., Balagansky, V.V., Timmerman, M.J., Marker, M., Bushmin, S.A., Alexeyev, N.L. and Daly, J.S., 2001. Age and provenance of early Precambrian metasedimentary rocks in the Lapland-Kola Belt, Russia: evidence from $\mathrm{Pb}$ and $\mathrm{Nd}$ isotopic data. Terra Nova, 13, 3237.

Dallmeyer, R.D., 1975. ${ }^{40} \mathrm{Ar} /{ }^{39} \mathrm{Ar}$ ages of biotite and hornblende from a progressively remetamorphosed basement terrane: their bearing on interpretation of release spectra. Geochimica et Cosmochimica Acta, 39, 1655-1669.
Daly, J.S., Balagansky, V.V., Timmerman, M.J., Whitehouse, M.J., de Jong, K., Guise, P., Bogdanova, S., Gorbatschev, R. and Bridgwater, D., 2001. Ion microprobe $\mathrm{U}-\mathrm{Pb}$ zircon geochronology and isotopic evidence for a transcrustal suture in the Lapland-Kola Orogen, northern Fennoscandian Shield. Precambrian Research, 105, 289-314.

Gaber, L.J., Foland, K.A. and Corbató, C.E., 1988. On the significance of argon releasefrom biotite and hornblende during ${ }^{40} \mathrm{Ar} /{ }^{39} \mathrm{Ar}$ vacuum heating. Geochimica et Cosmochimica Acta, 52, 2457 2465 .

Harrison, T.M. and Fitz Gerald, J.D., 1986. Exsolution in hornblende and its consequences for ${ }^{40} \mathrm{Ar} /{ }^{39} \mathrm{Ar}$ age specta and closure temperature. Geochimica et Cosmochimica Acta, 50, 247-253.

Harrison, T.M. and McDougall, I., 1980. Investigation of an intrusive contact, northwest Nelson, New Zealand, II. Diffusion of radiogenic and excess ${ }^{40} \mathrm{Ar}$ in hornblende revealed by ${ }^{40} \mathrm{Ar} /{ }^{39} \mathrm{Ar}$ age spectrum analysis. Geochimica et Cosmochimica Acta, 44, 2005-2020.

de Jong, K., Kurimoto, C. and Guise, P.G., 2000. ${ }^{40} \mathrm{Ar} /{ }^{39} \mathrm{Ar}$ whole-rock dating of metapelites from the Mikabu and Sambagawa belts, western Kii peninsula, southwest Japan. Journal of the Geological Society of Japan, 106, 703-712.

de Jong, K., Timmerman, M.J., Guise, P.G., Cliff, R.A., Daly, J.S., Balagansky, V.V. and Rex, D.C., 1999. The Paleoproterozoic Lapland-Kola Orogen (Russia): late-stage thermal resetting and the existence of tectonic phases, shown by ${ }^{40} \mathrm{Ar} /{ }^{39} \mathrm{Ar}$ mineral ages. Journal of Conference Abstracts, 4, 124.

Kelley, S.P. and Turner G., 1991. Laser probe ${ }^{40} \mathrm{Ar}-{ }^{39} \mathrm{Ar}$ measurements of loss profiles within individual hornblende grains from the Giants Range Granite, northern Minnesota, USA. Earth and Planetary Science Letters, 107, 634-648.

Lee, J.K.W., 1993. The argon release mechanisms of hornblende in vacuo. Chemical Geology, 106, $133-170$.

Lee, J.K.W., Onstott, T.C. and Hanes, J.A., 1990. An ${ }^{40} \mathrm{Ar} /{ }^{39} \mathrm{Ar}$ investigation of the contact effects of a dyke intrusion, Kapuskasing Structural Zone, Ontario: comparison of laser microprobe and furnace extraction techniques. Contributions to Mineralogy and Petrology, 105, 87-105.

Lee, J.K.W., Onstott, T.C. Cashman, K.V., Cumbest, R.J. and Johnson, D., 1991. A critical evaluation of the ${ }^{40} \mathrm{Ar} /{ }^{39} \mathrm{Ar}$ incremental heating of hornblende. Geology, 19, 872-876.

Lister, G.S. and Baldwin, S.L., 1996. Modeling the effect of arbitrary P-T-t histories on argon diffusion in minerals using the MacArgon program for the Apple Macintosh. Tectonophysics, 253, 83-109. 
Lo, C.-H. and Onstott, T.C., 1995. Rejuvenation of K-Ar systems for minerals in the Taiwan Mountain Belt. Earth and Planetary Science Letters, 131, 71-98.

McDougall, I. and Roksandic, Z., 1974. Total fusion ${ }^{40} \mathrm{Ar}{ }^{39} \mathrm{Ar}$ ages using HIFAR reactor. Geological Society of Australia Journal, 21, 81-89.

Mitrofanov, F.P., (ed.), 2001. Geological map of the Kola region. Scale 1:500000. Geological Institute of the Kola Science Centre, Russian Academy of Science, Apatity.

Onstott, T.C. and Peacock, M.W., 1987. Argon retentivity: Temperature, pressure and compositional effects. Geochimica et Cosmochimica Acta, 49, 24612468.

Onstott, T.C. and Pringle-Goodell, L., 1988. The influence of microstructures on the relationship between argon retentivity and chemical composition of hornblende. Geochimica et Cosmochimica Acta, 52, 2167-2168

Pushkarev, Yu.D., 1990. Megacycles in the Evolution of the Crust-Mantle System. Nauka, Leningrad (in Russian).

Rex, D.C. and Guise, P.G., 1986. Age of the Tinto felsite, Lanarkshire: a possible ${ }^{40} \mathrm{Ar}{ }^{39} \mathrm{Ar}$ monitor. Bulletin of Liaison Informations, IGCP Project 196, 6, 8-9.

Rex, D.C., Guise, P.G. and Wartho, J.-A., 1993. Disturbed ${ }^{40} \mathrm{Ar}{ }^{39} \mathrm{Ar}$ spectra from hornblendes thermal loss or contamination? Chemical Geology, 103, 271-281.

Ross, J.A. and Sharp, W.D., 1988. The effects of subblocking temperature metamorphism on the $\mathrm{K} / \mathrm{Ar}$ systematics of hornblendes: ${ }^{40} \mathrm{Ar} /{ }^{39} \mathrm{Ar}$ dating of polymetamorphic garnet amphibolite from the Franciscan Complex, California. Contributions to Mineralogy and Petrology, 100, 213-221.

Steiger, R.H. and Jäger, E., 1977. Subcommission on geochronology: convention on the use of decay constants in geo- and cosmology. Earth and Planetary Science Letters, 36, 359-362.

Sturt, B.A., Melezhik, V.A. and Ramsay, D.M., 1994. Early Proterozoic regolith at Pasvik, NE Norway: palaeoenvironmental implications for the Baltic Shield. Terra Nova, 6, 618-633.

Timmerman, M.J., 1996. Crustal evolution of the Kola region, Baltic Shield, Russia. Unpubl. Ph.D. Thesis, Nat. Univ. Ireland, Dublin, 233 pp.

Timmerman, M.J. and Daly, J.S., 1995. Sm-Nd evidence for late Archaean crust formation in the LaplandKola Mobile Belt, Kola Peninsula, Russia and Norway. Precambrian Research, 72, 97-107.

Turner, G., 1969. Thermal histories of meteorites by the ${ }^{39} \mathrm{Ar}-{ }^{40} \mathrm{Ar}$ method, In: Meteorite Research (P.M. Millman, ed.), pp. 407-417. Reidel, Dordrecht.
Turner, G., Huneke, J.C., Podosek, F.A. and Wasserburg, G.J., 1971. ${ }^{40} \mathrm{Ar}^{-39} \mathrm{Ar}$ ages and cosmic ray exposure ages of Apollo 14 samples. Earth and Planetary Science Letters, 12, 19-35.

Verschure, R.H., 1978. A microscope-mounted drill to isolate microgram quantities of mineral material from thin and polished sections. Minerological Magazine, 42, 499-503.

Vetrin, V.R., 1988. The oldest rapakivi-like granites of the Kola Peninsula. Doklady, Transactions of the USSR Academy of Sciences, 292, 98-102.

Vetrin, V.R., Bayanova, T.B., Kamensky, I.L. and Ikorsky, S.V., 2002. U-Pb age and Helium isotope geochemistry of rocks from the Litsa-Araguba diorite-granite complex (Kola Peninsula). Doklady, Transactions of the Russian Academy of Sciences, 387, 85-89.

Villa, I.M., Grobéty, B., Kelley, S.P., Trigila, R. and Wieler, R., 1996. Assessing Ar transport paths and mechanisms in the McClure Mountains hornblende. Contributions to Mineralogy and Petrology, 126, 67-80.

Villa, I.M., Hermann, J, Müntener, O, and Trommsdorff, V. $2000 .{ }^{39} \mathrm{Ar}-{ }^{40} \mathrm{Ar}$ dating of multiply zoned amphibole generations (Malenco, Italian Alps). Contributions to Mineralogy and Petrology, 140, 363-381.

Wartho, J-A., 1995a. Photo-emission electron microscopy (PEEM) heating investigations of a natural amphibole sample. Mineralogical Magazine, 59, 121-127.

Wartho, J.-A., 1995b. Apparent argon diffusive loss ${ }^{40} \mathrm{Ar} /{ }^{39} \mathrm{Ar}$ spectra in amphiboles. Earth and Planetary Science Letters, 134, 393-407.

Wartho, J-A., Dodson, M.H., Rex, D.C. and Guise, P.G., 1991. Mechanisms of Ar release from Himalayan metamorphic hornblende. American Mineralogist 76, 1446-1448.

Wijbrans, J.R. and McDougall, I., 1987. On the metamorphic history of an Archean greenstone terrane, East Pilbara, Western Australia, using the ${ }^{40} \mathrm{Ar}{ }^{39} \mathrm{Ar}$ age spectrum technique. Earth and Planetary Science Letters, 84, 226-242.

Wijbrans, J.R., Pringle, M.S. Koppers, A.A.P. and Scheveers, R., 1995. Argon geochronology of small samples using the vulkaan argon laserprobe. Proceedings Koninklijke Nederlandse Akademie van Wetenschappen, Series B, 98, 185-218.

Zagorodny, V.G. (ed.), 1982. The Imandra - Varzuga Zone of the Karelides. Nauka, Leningrad (in Russian).

Received 14 October 2005; revised version accepted 11 July 2006 